Florida International University FIU Digital Commons

5-24-2013

\title{
The Survival and Stock Performance of Emerging Country Firms in the United States
}

\author{
Kun Yang \\ Florida International University, kyang001@fiu.edu
}

DOI: $10.25148 /$ etd.FI13080722

Follow this and additional works at: https://digitalcommons.fiu.edu/etd

Part of the Business Administration, Management, and Operations Commons, and the International Business Commons

\section{Recommended Citation}

Yang, Kun, "The Survival and Stock Performance of Emerging Country Firms in the United States" (2013). FIU Electronic Theses and Dissertations. 928.

https://digitalcommons.fiu.edu/etd/928

This work is brought to you for free and open access by the University Graduate School at FIU Digital Commons. It has been accepted for inclusion in FIU Electronic Theses and Dissertations by an authorized administrator of FIU Digital Commons. For more information, please contact dcc@fiu.edu. 
FLORIDA INTERNATIONAL UNIVERSITY

Miami, Florida

THE SURVIVAL AND STOCK PERFORMANCE OF EMERGING COUNTRY FIRMS IN THE UNITED STATES

A dissertation submitted in partial fulfillment of

the requirements for the degree of

DOCTOR OF PHILOSOPHY

in

BUSINESS ADMINISTRATION

by

Kun Yang

2013 
To: Dean David R. Klock

College of Business

This dissertation, written by Kun Yang, and entitled The Survival and Stock Performance of Emerging Country Firms in The United States, having been approved in respect to style and intellectual content, is referred to you for judgment.

We have read this dissertation and recommend that it be approved.

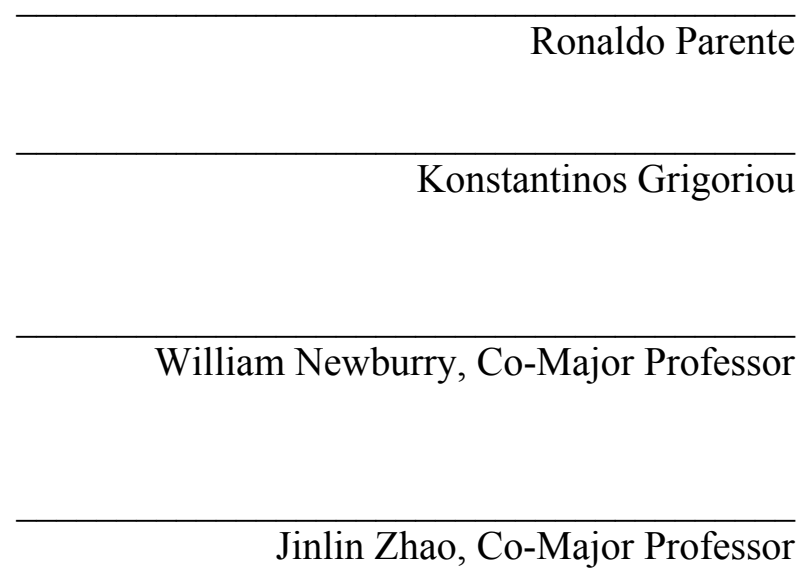

Date of Defense: May 24, 2013

The dissertation of Kun Yang is approved.

Dean David R. Klock College of Business

Dean Lakshmi N. Reddi University Graduate School

Florida International University, 2013 
(C) Copyright 2013 by Kun Yang

All rights reserved. 


\section{DEDICATION}

I dedicate this dissertation to my parents, Wenjuan Feng and Juqing Yang.

Without their understanding, support, and most of all love, the completion of this work would not have been possible. 


\section{ACKNOWLEDGMENTS}

I gratefully thank my dissertation committee, Jinlin Zhao, William Newburry, Ronaldo Parente, and Konstantinos Grigoriou. First and foremost, I would like to express my deep respect and gratitude to my two major advisors, Dr. Jinlin Zhao and Dr. William Newburry. Over the past 5 years, Dr. Zhao was always available when I needed his help. His diligence and dedication to the work greatly impressed me. As a mentor, he offered me abundant instructions, father-like care, and unreserved support in my academic research, dissertation writing, and career development. Dr. William Newburry's “start now" and methodical work style very much influenced me. He provided me with invaluable suggestions and help on the dissertation development, writing timeline, committee revising, and so on. This dissertation would not have been completed without the two advisors' guidance and input during the entire process of the dissertation writing. I owe a debt of gratitude to Dr. Ronaldo Parente, who was always positive and passionate about my research and career development. He is a friendly, helpful, and creative professor who gave me constructive advice on my dissertation, and great encouragement and sincere support in my career development. I also give special thanks to Dr. Konstantinos Grigoriou, whom I asked only recently to join my committee. I am very happy that he was kind enough to accept my invitation and share his insights on my dissertation and the further development of the essays.

Some other professors have provided excellent advice and kind help during the development of this dissertation and my study in the Ph.D. program, including William Schneper, Summit Kundu, Isadore Newman, Aya Charcar, Joan Remington, and Scott Kass. I am indebted to Dr. William Schneper, who generously invested hours in 
brainstorming ideas for my dissertation at the early stage of dissertation writing, advising me on data collection using new statistical tools for our project, and introducing me to survival analysis, which is the main statistical method I used in the dissertation. I give special thanks to Dr. Sumit Kundu, who sincerely gave me great encouragement at almost every stage of my Ph.D. study. He provided me with constructive suggestions during my proposal defense and final dissertation defense. Dr. Isadore Newman also has my gratitude for clearing my doubts regarding the method of survival analysis and guiding me to read some good books on this method. My thanks also go to Dr. Aya Charcar, who loves and cares students. In her seminar, she helped and "forced" me to complete the first empirical paper in my life. I would also like to extend my genuine thanks to Professor Joan Remington. I'm truly blessed to have her support for the opportunity of pursuing the Ph.D. degree that further extended my academia career. I would also thank Professor Scott Kass, an expert in English, for his kind and generous help in proofreading the whole manuscript carefully and efficiently.

I would like to thank my fellow doctoral students who made the 5 years of study such a positive and memorable experience for me. I am grateful to Abrahim Soleimani for his kind help. He was extremely helpful and supportive in answering my questions about comprehensive exams and the dissertation writing. I would like to thank Rimi Zakaria, Elda Ceribashi, and Yannick Thams, with whom I shared the happiness and frustrations during the intense Ph.D. study. I also thank Armando Borda, Yukai Wang, Watcharaphong Leartsurawat, Sokol Celo, Abdul Beydoun, Dina Zaher, Kieth Kelly, Marcelo Vargas, Ying Liu, Santhosh Narayanan, Sayed Afjei, and Jun Yang for their 
encouragement, inspiration, and insightful academic support throughout the entire Ph.D. journey.

I dedicate this dissertation to my dear, lovely parents, Juqing Yang and Wenjuan Feng, who have provided me with tremendous love, unshakable confidence, unconditional support, and consistent encouragement throughout every stage of my life. Their roles in shaping my optimistic attitudes towards life and forging my strong confidence in pursuing this career are priceless. Moreover, my gratitude goes to my parents-in-law and sister-in-law, whose love and concern accompanied me through the whole process of my Ph.D. study. Finally, I wish to thank my husband, Wei He, who used to study in the same Ph.D. program and experienced all the ups and downs during the entire process of my Ph.D. study. It is not easy to be the spouse of a doctoral student. Not to mention, he was a doctoral student and simultaneously another doctoral student's spouse. I am grateful to his love, understanding, and support during my dissertation writing. This dissertation would not have been possible if it were not for my family. 


\title{
ABSTRACT OF THE DISSERTATION \\ THE SURVIVAL AND STOCK PERFORMANCE OF EMERGING \\ COUNTRY FIRMS IN THE UNITED STATES
}

\author{
by \\ Kun Yang \\ Florida International University, 2013 \\ Miami, Florida \\ Professor Jinlin Zhao, Co-Major Professor \\ Professor William Newburry, Co-Major Professor
}

Many firms from emerging markets flocked to developed countries at high cost with hopes of acquiring strategic assets that are difficult to obtain in home countries. Adequate research has focused on the motivations and strategies of emerging country firms' (ECFs') internationalization, while limited studies have explored their survival in advanced economies years after their venturing abroad. Due to the imprinting effect of home country institutions that inhibit their development outside their home market, ECFs are inclined to hire executives with international background and affiliate to world-wide organizations for the purpose of linking up with the global market, embracing multiple perspectives for strategic decisions, and absorbing the knowledge of foreign markets. However, the effects of such orientation on survival are under limited exploration.

Motivated by the discussion above, I explore ECFs' survival and stock performance in a developed country (U.S.). Applying population ecology, signaling theory and institutional theory, the dissertation investigates the characteristics of ECFs that survived in the developed country (U.S.), tests the impacts of global orientation on their survival, 
and examines how global-oriented activities (i.e. joining United Nations Global Compact) affect their stock performance. The dissertation is structured in the form of three empirical essays. The first essay explores and compares different characteristics of ECFs and developed country firms (DCFs) that managed to survive in the U.S. The second essay proposes the concept of global orientation, and tests its influences on ECFs' survival. Employing signaling theory and institutional theory, the third essay investigates stock market reactions to announcements of United Nation Global Compact (UNGC) participation.

The dissertation serves to explore the survival of ECFs in the developed country (U.S.) by comparison with DCFs, enriching traditional theories by testing non-traditional arguments in the context of ECFs' foreign operation, and better informing practitioners operating ECFs about ways of surviving in developed countries and improving stockholders' confidence in their future growth. 


\section{TABLE OF CONTENTS}

ESSAY

PAGE

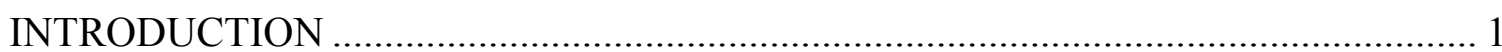

ESSAY 1. The comparison of the survival of emerging country (China) firms and developed country (U.K.) firms in U.S....................................................................... 7

ABSTRACT

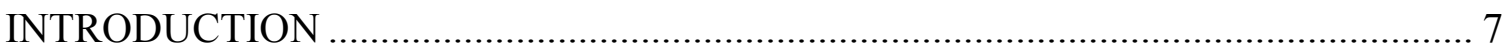

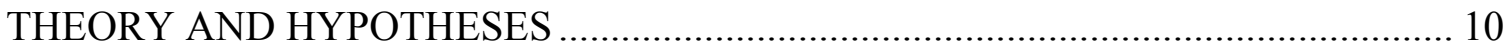

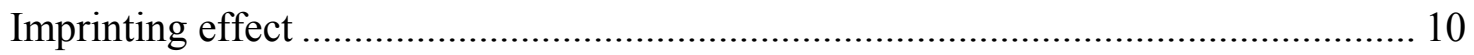

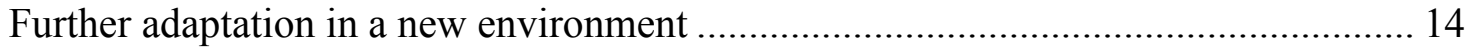

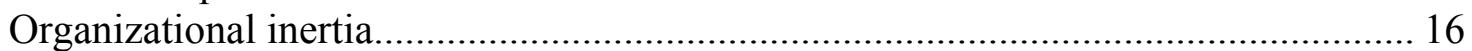

Different forms of international experience........................................................... 18

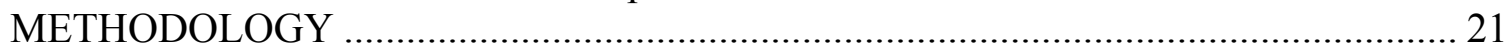

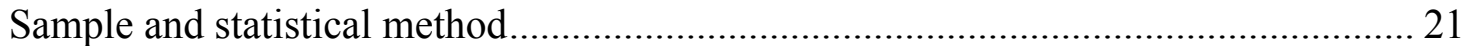

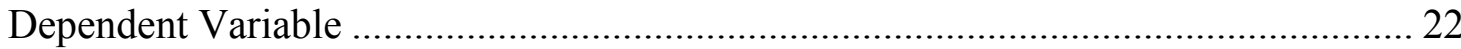

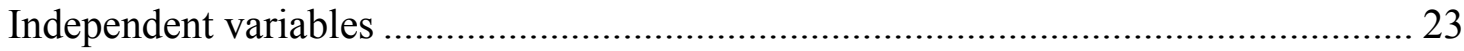

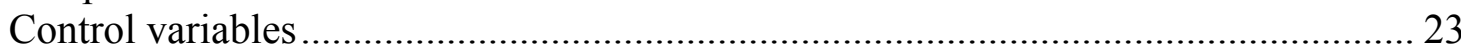

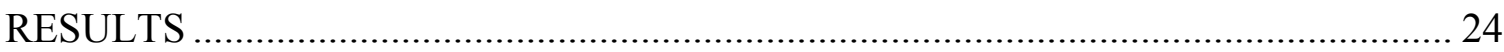

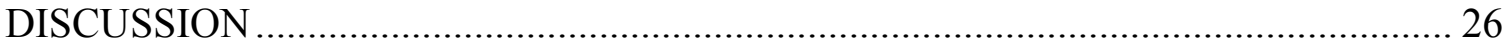

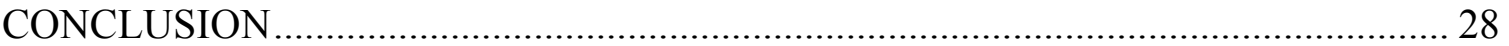

LIMITATIONS AND FUTURE RESEARCH.......................................................... 30

ESSAY 2. Global orientation and emerging country (China) firms' survival in the U.S.

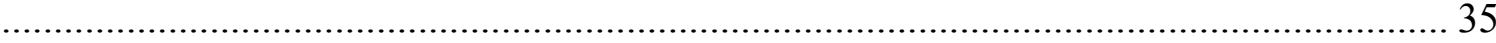

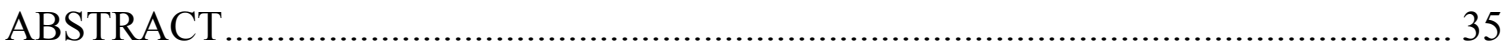

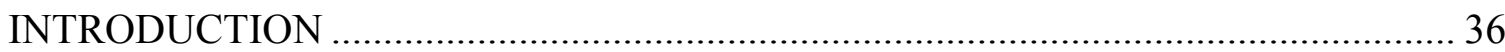

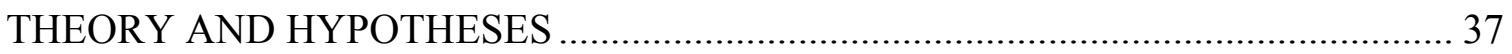

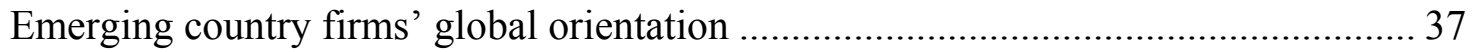

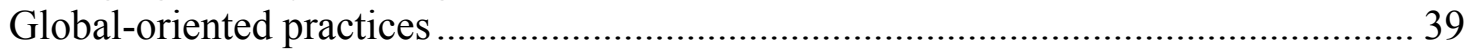

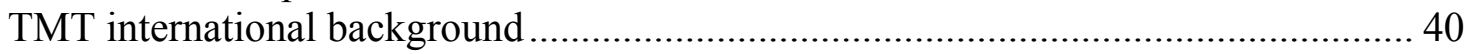

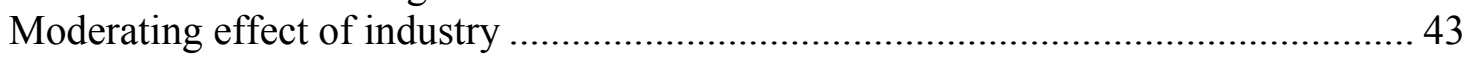

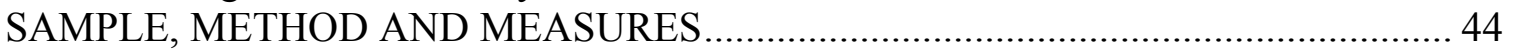

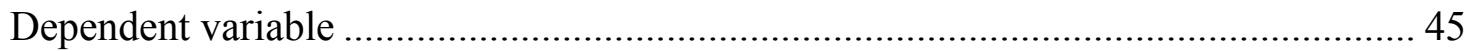

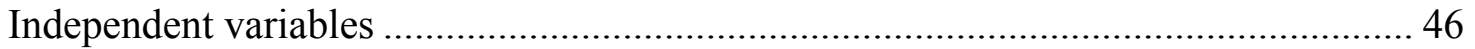

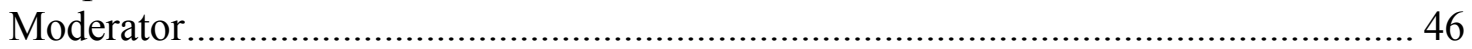

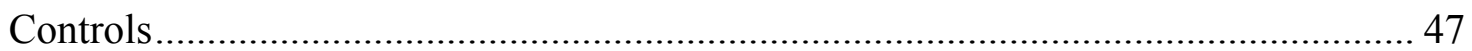

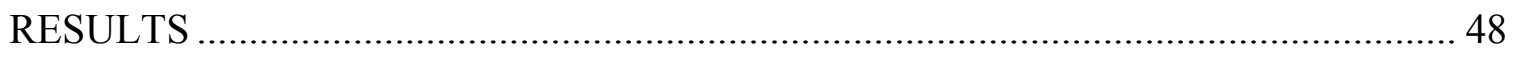

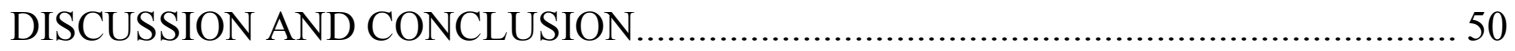

ESSAY 3. UNGC participation announcements and stock market reactions: signaling and institutional perspectives on the effects of firm-level and country-level attributes.......... 57

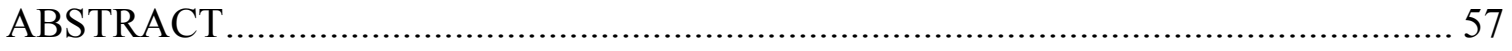

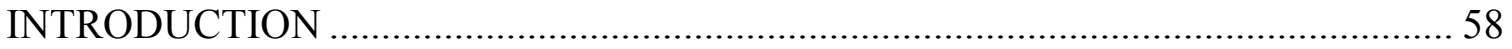




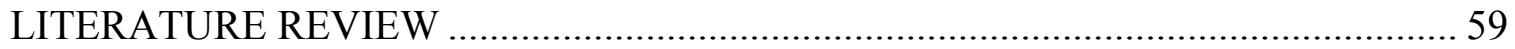

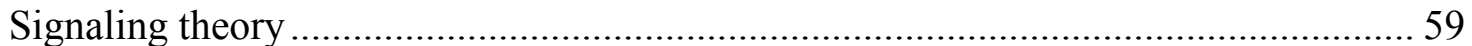

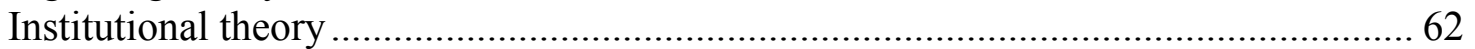

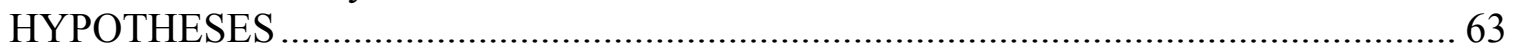

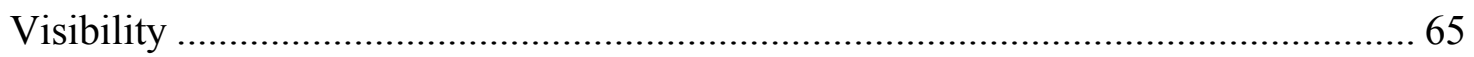

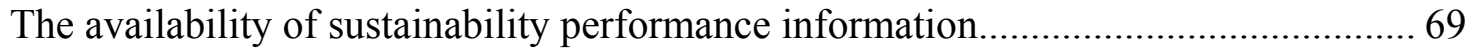

Moderating effects of the home country type ................................................... 70

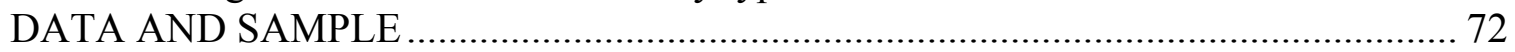

Dependent variable .......................................................................................... 72

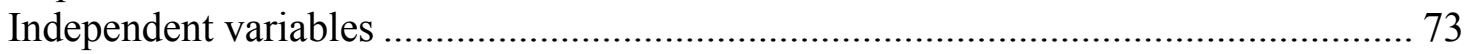

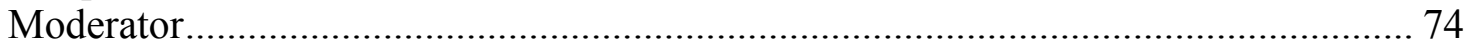

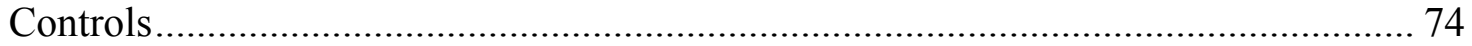

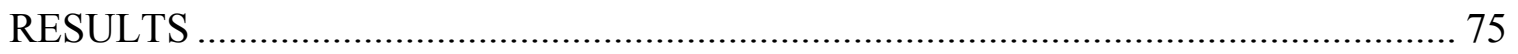

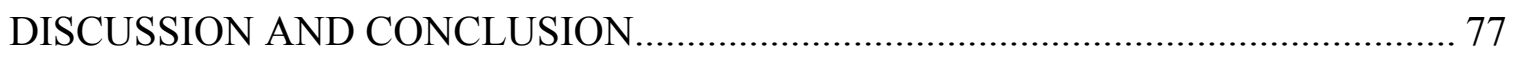

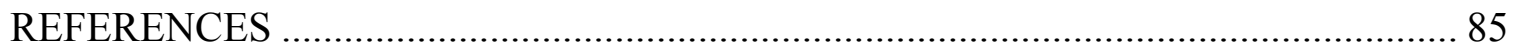

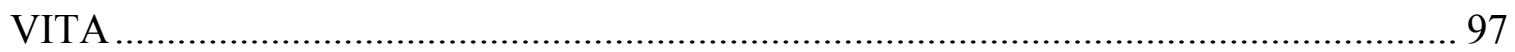




\section{LIST OF TABLES}

TABLE

PAGE

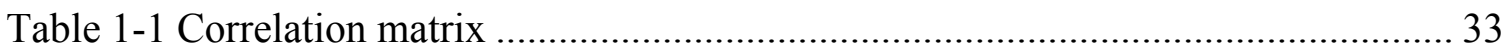

Table 1-2 Survival of DCF/ECF subsidiaries in the US ............................................... 34

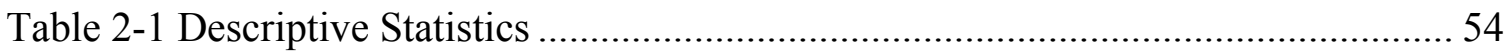

Table 2-2 Weibull survival analysis on emerging country firms' global orientation....... 55

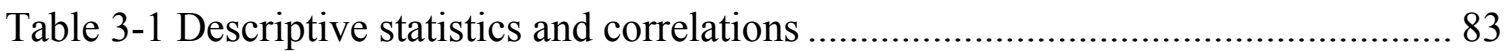

Table 3-2 Regression results for Market Reaction to UNGC participation Announcement

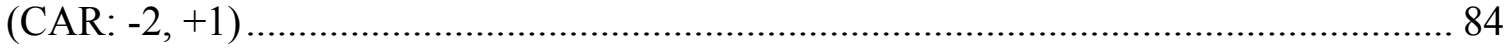




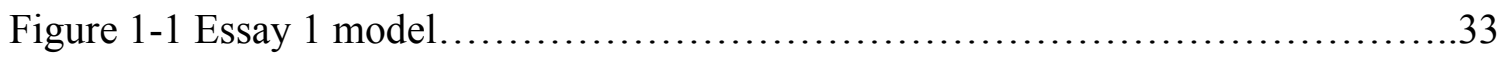

Figure 1-2 Survival trajectory of U.K. firms (group 0) and China (group 1) .................. 32

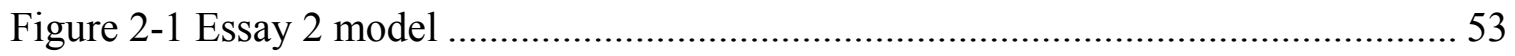

Figure 3-1 Communication between signal and market ................................................ 81

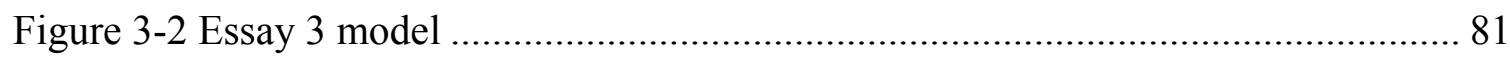

Figure 3-3 Impact of firm visibility on market reaction to UNGC participation

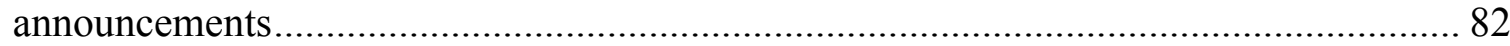

Figure 3-4 Impact of visibility on market reaction to UNGC participation announcements for firms from two types of home country .................................................................... 82 


\section{INTRODUCTION}

Firm survival has been widely studied in the literature of Organizational Theory from the perspectives of organizational ecology (Hannan \& Freeman, 1977, 1989), resource dependence (Pfeffer \& Salancik, 1978), and institutional theory (DiMaggio \& Powell, 1983). These theories emphasize the impact of interactions between organizations and the environment on organizations' survival. Organizational ecology underscores the match between organizational characteristics and the external environment on organizations' survival. A resource dependence perspective places the emphasis on organizational control of external resources. Institutional theory stresses that survival depends on conformity with other legitimate organizations. Compared with organizational theory, which focuses on survival, theories in international business and strategy lay more emphasis on the influential factors of firm growth and firm (financial \& social) performance. For example, "the cost of doing business abroad" (Hymer, 1976) and the "liability of foreignness" (Zaheer, 1995) highlight the extra burdens charged to foreign firms compared with local firms in host countries. The resource based view (Barney, 1991; Penrose, 1959) emphasizes firm heterogeneity, differences in the way resources are applied and combined, leading to competitive advantages that are valuable, rare, inimitable and non-substitutable (Barney, 1991).

Empirical studies on firm survival generally examine the influential factors at four different levels: industry level, firm level, population level, and individual level. Industry-level factors include changes in industry (Haveman, 1992), industry growth (Hennart \& Park, 1993; Driffield \& Munday, 1997), service versus manufacturing 
industries (i.e., Nessereddine, 2012), and technical change (Barnett, 1990). Firm-level factors such as experience related to the industry (Tan, 2010), firm age (Caves, 1998; Klepper, 2002; Zimmerman \& Zeitz, 2002), organization form (Mudambi \& Zahra, 2007), entry mode (Kogut, 1988), and product life cycle (Agarwal \& Gort, 2002) can also explain firms' vitality. Population-level factors including ethnicity identity (Miller, Thomas, Eden, \& Hitt, 2008), and density-dependence (Carroll \& Hannan, 1989; Banaszak-Holl, Ranger-Morre, \& Hannan, 1990; Mitchell, 1989; Li, 1992; Hannan \& Freeman, 1989) also determine firms' survival. Moreover, individual-level factors, such as owners' education and gender (Saridakis, Mole, \& Storey, 2008) and CEO succession (Singh, Tucker, \& House, 1986) are found to be influential to firm survival.

Nevertheless, of the many empirical studies exploring the factors influencing firm survival, most emphasize the impact of external factors on firms' survival, leaving the imprinting effect (Stinchcombe, 1965) of the firms under limited exploration. The imprinting effect holds that firms are bound by their original choices and circumstance of founding and that they have limited abilities to adapt. This effect should be particularly apparent for ECFs that operate in developed countries. Emerging countries have undeveloped institutions with poor regulatory quality and low control of corruption (Cuervo-cazurra \& Genc, 2008). Besides the impact of changes of external environment, the embedded characteristics of firms, such as organizational practices, structures, and mindset that were forged in their home countries, play critical roles in their operation in a new environment which is quite different from that of their home countries. With ECFs' rapid internationalization in the global market, it is imperative to investigate the survival 
of these new species (ECFs) with "weak genes" that were nurtured in their home environment.

In the real world, some ECFs have achieved considerable success in the global market, such as TaTa and Wipro from India, CEMEX from Mexico, Embraer from Brazil, and Huawei from China. Very recently, Shuanghui, China's biggest pork producer, has announced its purchase of Smithfield Foods, the 87-year-old American meat giant, for $\$ 4.7$ billion in cash in June 2013. This transaction would be the biggest takeover of an American company by a Chinese concern, if completed (De La Mercedb \& Barboza, 2013). These ECFs have stronger resources than many of their developed market competitors (Bartlett \& Ghoshal, 2000; Khanna \& Palepu, 2006; Makino, Lau, \& Yeh, 2002), and thus, they are more likely to outlive other competitors in the global market.

However, these ECFs tend to be exceptions (Thomas, Eden, Hit, \& Millter, 2007); there are many more cases of failure. Suntech Power, a Chinese firm listed on the New York Stock Exchange, and one of the world's largest makers of solar panels, collapsed into bankruptcy and closed its factory in Arizona in March 2013 (Bradsher, 2013). Little Sheep, a Chinese restaurant multinational with over 360 stores in Asia and North America, was acquired by Yum! Brand in 2011 and was delisted in February 2012 (China Scope Financial, 2011). Huawei and ZTE, China's top telecommunications gear makers, have experienced challenges on their rough road of marching into the U.S. market. In October 2012, a Congressional report suggested that the U.S. government should block acquisitions or mergers by Huawei and ZTE. The House Intelligence Committee report stated that the companies failed to cooperate with a yearlong investigation and to 
adequately explain their U.S. business interests and relationship with the Chinese government (Wolf, 2012).

Besides ECFs, DCFs also face challenges of survival in the global market. They receive imprinting effects that are different from those received by ECFs because DCFs come from developed countries which are quite different from developing countries, Thereby, their survival situation may be quite the different from that of ECFs. Thus, it is quite interesting and meaningful to compare the two types of firms' survival trajectory and investigate the influences of different factors on their survival. The first essay of the dissertation fills this gap in the current literature by comparing Chinese firms' and UK firms' survival and taking into consideration the impact of imprinting effects and organizational inertia. Essay One is perhaps the first paper comparing the influential factors of ECFs' and DCFs' survival in the international business (IB) literature, one of the few studies that emphasize the impact of imprinting effects of home environment on firms' survival, and one of the few studies of firms' survival on the subsidiary level. Furthermore, the results provide empirical implications for practitioners. Results show the factors that are important to the survival of ECFs and DCFs, respectively, clarify different survival trajectories in the U.S. and shed light on the ways of surviving and competing with their rivals in the U.S.

In addition to comparing the survival between ECFs and DCFs, the dissertation proposes a strategy that ECFs tend to use in a foreign market, defined as global orientation in Essay Two. It refers to ECFs' propensity to establish management teams with global mindsets and to participate in globally oriented activities. The purpose of the 
strategy is to absorb knowledge regarding operating in foreign markets and mitigate the imprinting effect of their home countries' institutions on their global operations. Whether this strategy exerts a positive influence on ECFs' survival is unknown. Essay Two tests the association of each component of global orientation on ECFs' survival based on this new definition. Essay Two contributes to the literature of global mindset and survival by exploring the global mindset on the organizational level (in the current literature global mindset is studied mostly on the individual level) and by linking the global mindset to firms' survival in the context of emerging country (China) firms operating in the U.S. The findings yield some empirical contributions to ECFs' practitioners. It shows how a Top Management Team (TMT)'s composition and global-oriented practices are associated with an ECF's survival.

Furthermore, the dissertation tests firms' stock performance in the context of United Nations Global Compact (UNGC) participation. Drawing on signaling theory and institutional theory, Essay Three investigates the stock market reactions to the announcements of firms' UNGC participation. Moreover, it tests the moderating effect of a country-level factor, home country type, on the relationship between firm-level attributes and stock market reactions. The paper contributes to the literature on signaling theory by closely investigating the dynamics between the focal signal and firm-level attributes, and by firstly addressing the positive impact of the information vacancy on the effectiveness of the focal signal's delivery. The research also enriches the literature related to affiliation in two ways. First, it examines the explanatory factors of market reactions at multiple levels. It captures the firm-level attributes' direct influence and 
country-level's moderating effect on the market reaction to the announcement of UNGC participation. Second, it proposes the inverted affiliation, a notion pointing out the bidirectional affiliation between the firm and affiliation organizations (i.e., UNGC). Moreover, the findings of Essay Three provide practical implications to practitioners, particularly those of ECFs, on the developed foreign markets by empirically investigating the effective ways of receiving positive market reaction to affiliation and boosting investors' confidence in their performance and future development.

This dissertation contributes to the literature of International Business by taking the first stride in investigating ECFs' survival trajectory compared with that of DCFs operating in the same developed market, the U.S. I also hope it enriches the literature on survival by emphasizing the impact of imprinting effects on firms' survival. This dissertation is also intended to add the global orientation strategy to the literature of the emerging market, and to enrich the literature of global mindset by studying global mindset on the organizational level. I also hope it further develops signaling theory and affiliation theory by adding the notions of information vacancy and inverted affiliation. Finally, I do hope the dissertation holds value for practitioners by firstly providing some empirical implications for ECFs operating in developed countries and DCFs competing with rivals from emerging markets. It sheds light on how ECFs survive in the U.S., and what factors ECFs need to stress for vitality. It also examines and compares the effectiveness of certain strategies for ECFs and DCFs, such as affiliation, on boosting investors' confidence in their future performance. 


\section{ESSAY 1. The comparison of the survival of emerging country (China) firms and developed country (U.K.) firms in U.S.}

\section{INTRODUCTION}

As the international economic balance continues to shift from the West to the East, companies from emerging markets are internationalizing their operations in an accelerating manner. One of their motivations for operating abroad is to acquire strategic assets that are difficult to obtain in their home countries (Luo \& Tung, 2007). Another motivation is to seek an advanced institutional environment where the market plays a major role in economic transactions, and firms are more protected. Thus, the expected consequences of these investments in developed countries are to have more opportunities, more strategic assets, a more comfortable environment in which ECFs can grow, and even better performance than they had in their home countries. However, it is also argued that acquisitions of target firms in weak institutional environments have more potential to yield better post-acquisition performance, because the target's development was more likely to be constrained by the poor legal protection and non-marketed-based economies in their home countries (Feito-Ruiza \& Menendez-Requejo, 2011; Rossi \& Volpin, 2004). While in the opposite situation, acquisitions of target firms from developed countries tend to perform poorly in a more favorable environment, indicating that it is more challenging for ECFs to improve the target firms' performance in developed countries.

Despite the heated discussion about ECFs' motivations and strategies of internationalization, limited empirical research has examined ECFs' survival in advanced economies. This essay is aimed to investigate ECFs' survival in the U.S. while comparing this with DCFs' survival. In addition, the paper investigates whether factors related to 
imprinting effects such as relative size, ownership, legal status and international experiences affect their survival.

This paper employs organization ecology theory (Hannan \& Freeman, 1977, 1984) to investigate whether the theory is applicable in the context of ECFs' internationalization. One of the theory's fundamental assertions is that demographic factors such as size (Hannan \& Freeman, 1977; Aldrich \& Auster, 1986; Hannan \& Freeman, 1989; Hannan, Ranger-Moore, \& Banaszak-Hall, 1990; Barnett \& Amburgey, 1990), age (Stinchcombe, 1965; Carroll, 1983; Freeman, Carroll, \& Hannan, 1983; Hannan \& Freeman, 1989), inertia, and prior experience (Miller et al., 2008; Thomas, Eden, Hitt, \& Miller, 2007) influence the survival of firms. But traditional researchers looked mainly at the DCFs investing in developing and developed countries, and it's a relatively new phenomenon that ECFs step on the international stage and start business in brand new environments. Organizational theory holds that the imprinting effect persists beyond the founding phase, and probably has lifelong consequence (Hannan \& Freeman, 1989; Stinchcombe, 1965). However, this point has rarely empirically tested in the current literature. I argue that the imprinting effect is particularly apparent in the context of ECFs' internationalization and survival in the developed countries. For the purpose of bridging this research gap, this paper investigated the influences of imprinting effect on ECFs' survival in the developed country (U.S.), and analyzed how the imprinting effect determines the survival of this new species with "weak genes" that were cultivated and obtained from the developing home environment. 


\begin{abstract}
This essay studies the survival of emerging country firms (ECFs) in a developed country (the U.S.) and compares their survival with developed country firms (DCFs) in the same host country, U.S. Applying organizational ecology and institutional theory, the paper depicts the survival trajectory of the two types of firms, compares DCFs with ECFs, and points out differences in which factors influence survival of firms from emerging and developed countries. Taking Chinese firms and U.K. firms as examples, the empirical results support the arguments that firms' relative size, legal status, and international experiences impact the survival of ECFs and DCFs in the U.S. New to the current literature, the results show that a large relative size threatens ECFs' survival while it strengthens DCFs' vitality. Listed legal status negatively impacts ECFs' survival, but it tends to benefit DCFs in the U.S. Ownership does not have significant impact on ECFs' survival. The moderating effects of international experience in both emerging markets and developed countries are discussed.
\end{abstract}

Keywords: survival analysis, emerging country firms, developed country firms, comparison 


\section{THEORY AND HYPOTHESES}

\section{Imprinting effect}

Organizational imprinting (Stinchcombe, 1965) holds that the conditions and resources available to organizations at founding will determine their initial structures and practices, which will persist well beyond the founding phase. ECFs carry their own ways of making decisions and setting up strategies which were developed in the home country. Their methods and practices of strategic management are not advanced compared with firms located in developed countries, where more advanced management styles and business models prevail. However, a different pattern applies to DCFs when they invest in developing countries. DCFs bring advanced technologies, more developed management styles and business models that are welcomed by the host countries. In this sense, the imprinting effects do not necessarily have negative impacts on operating in developing countries. In contrast, ECFs with an eagerness to learn will inevitably apply the imprinted organizational practices (Kostova, 1999) to new operations in developed countries, where the less advanced elements tend to be harmful to the new business. On the other hand, DCFs tend to carry stronger competencies while operating abroad; they are from developed countries which have smaller institutional and economic distances to the host environments than ECFs. Thus, the transfer of strategic organizational practices is more likely to succeed for DCFs than ECFs from emerging countries which have larger institutional and economic distances from the host (developed) countries (Kostova, 1999). Therefore, the positive imprinting effects are more likely to be favorable to DCFs' 
operations in host countries. Consequently, they have more chances of survival than ECFs in developed countries.

Hypothesis 1: The subsidiaries of DCFs have greater likelihoods of survival than those of ECFs in the U.S.

State-owned ECFs bear the heritage of their home country economies, which are often currently or formerly planned. Their particular ways of conducting organizational functions have been institutionalized and evolved over time under the influence of these planned economies. During national economic reform that has occurred in many developing nations, state-owned enterprises have been undergoing restructuring and marshaling resources. For the purpose of accelerating the completion of this restructuring, the government offers support to state-owned firms that invest abroad in terms of policy and finance. This positive effect is especially apparent at the early stage of entry, because the support from the government becomes a big push force and bolster for firms to invest abroad. Such a positive impact is more influential in the early years of operations. The government support may be provided in different forms, such as financial resources and social relationships; they serve as a stock of assets reducing the risk of mortality while supporting a honeymoon period at the early stage of operation (Fichman \& Levinthal, 1991).

Besides government support, ECFs tend to enjoy country-specific advantages based on low labor cost, or natural resource endowment and so on (Rugman \& Verbeke, 2003) at the beginning of their cross-border operations. The country-specific advantages 
tend to be the main source of their strengths at the inception of internationalization (Rugman, 2008). ECFs tend to consume these country-specific advantages at the early stage of entry and the likelihood of survival is higher than at later years of operation, because there is more likelihood for the state-owned ECFs to suffer the liability of adolescence (e.g. Henderson, 1999). Since ECFs are normally considered as firms with weak strengths, less innovation, and fewer managerial capabilities, most of which result from their replying on country-specific advantages, it is imperative for them to develop proprietary firm-specific advantages that allow them to compete internationally in a long run. In other words, state-owned ECFs turn out to be short of strengths with time due to the fact that their country-specific advantages are dissolving and their own firm-specific advantages are not established in a timely manner. In the meantime, the imprinting effects of state-owned firms' structure and management style may still prevail and hinder further healthy development.

On the other hand, private ECFs normally live in a restricted business environment in home countries, where they pay higher taxes, confront the interference by local governments, and have limited access to loans from state banks, market information, land and other resources (Asian Development Bank, 2002). Some of the discriminative environment still exists today (O’Neil, 2004). Private ECFs not only live in constraint in their home countries, but also receive limited governmental support abroad. They tend to have limited "honeymoon" at the early stage of the operation. With little external support and considerable liability of foreignness (Zaheer, 1995), private ECFs are less likely to survive at their early stage of operation than state-owned ECFs which receive more 
governmental support and have the privilege of financial resources. Thus, I hypothesize that,

Hypothesis 2a: At the early stage of foreign operation, state-owned ECFs' subsidiaries have greater likelihood to survive in the U.S. than do private-owned ECFS' subsidiaries.

Private ECFs investing in developed countries normally have less financial and policy support from their home governments than do the state-owned ECFs. So it becomes tougher for private ECFs at the beginning of foreign operation than for stateowned ECFs. Consequently, the possibility of private ECFs' survival is lower than that of state-owned ECFs at the initial stage of operation. However, the existence of private ECFs is the outcome of privatization. They do not possess the strong heritage of the planned economy, the low-efficient management system, or less advanced business model. They have more ability to adapt to the environment compared to the other group of state-owned ECFs in the same host country. This becomes their advantage in adapting to the new environment and leaves a solid foundation for further development. In addition, they go abroad based on their own strength and the fact that they possess limited imprinting from the planned economy. So they are flexible to learn and tend to quickly adapt to the new environment. This eases their way of learning and accumulating their own resources that could be considered rare, valuable, inimitable and non-substitutable resources (Barney, 1991). Therefore, private ECFs are more likely to survive at the later stage of operation. Thus, I argue that, 
Hypothesis 2b: At the later stage of operation, private-owned ECFs' subsidiaries have greater likelihood to survive in the U.S. than do state-owned ECFs' subsidiaries.

\section{Further adaptation in a new environment}

To be listed in the host stock market is a further step for foreign firms when assimilating into the local market and the legal environment; the listing obligates these firms to conform to the rules and regulations of the Securities Exchange Commission (SEC), whereas unlisted foreign firms do not have to do so. Because U.S.-listed foreign firms are subject to the regulatory requirements of the SEC, these firms are expected to disclose information (i.e., management earnings forecasts, ownership structure, board and management structure and process) in a way similar to that of U.S. firms.

Organizational practices (Kostova, 1999) are greatly influenced by the environment in which firms initially operate. Thus, U.S.-listed ECFs' disclosure behaviors are greatly influenced by their home countries' institutional environments. Home country institutions, including legal institutions, have prevalent economic consequences and affect the firm's business environment, such as ownership structure, labor rights, property rights, access to financing, firm valuation, contract enforcement, and information sharing (La Porta, Lopez-de-Silanes, \& Shleifer, 2008). These influential factors define the way and the extent to which firms voluntarily provide information. Shi, Magnan, and Kim (2012) found that voluntary disclosures are more favorable to firms from countries with stronger legal institutions. Also, Standard \& Poor's survey on transparency and disclosure shows that emerging markets, including Asian and Latin 
American countries, ranked the lowest for disclosure, following Europe, Japan, U.S., and U.K. (S\&P, 2002).

Therefore, getting accustomed to the stringent disclosure requirements of SEC is not a simple matter for emerging country firms listed in the U.S. market. To improve their transparency and information disclosure, ECFs need to shake off the inertia of their organizational practices that are imbedded in and influenced by their home countries, where less transparency and disclosure are encouraged. This should be a relatively long process for listed ECFs to further adapt and assimilate themselves into a new and stringently-developed business environment. Jiang and Kim (2005) found that disclosure levels of U.S. firms tend to be greater than those of U.S. - listed foreign firms. During this process, some ECFs may face difficulties in staying listed in the U.S. due to the stringent requirements, public scrutiny and poor performance, and some of them may go further to give up the "listed" legal status because they are not able to afford the requirements or maintain adequate performance. For instance, a Bloomberg index of the 12-month stock performance of nearly 80 Chinese reverse-merger firms peaked above 200 in November 2010 and was well below 100 at the end of 2011 (USA Today). Four Chinese firms (Harbin Electric on Nasdaq, Sinoenergy, China Security \& Surveillance, and Chemspec) that went public in the U.S. within the past few years have returned to private status, and a dozen more are in talks to do so (USA Today).

On the other hand, unlisted ECFs do not have the obligation to disclose their information or execute stock market rules and regulations that are required by SEC. Thus, they do not have to adapt themselves to such a stringent business environment, or 
assimilate themselves into a harsher stock market than their existing business environment. An important implication of the above discussion is that U.S.- listed ECFs tend to have shorter longevity than unlisted ECFs.

U.S. -listed DCFs come from a country where there is a more transparent stock market (S\&P, 2002) and thus it is much easier their practice in the U.S. stock market to meet the requirements of the SEC. There are generally no severe problems for developed country (U.K.) firms to get accustomed and overcome difficulties in assimilating into the new host market. On the contrary, with accustomed business practices in the host environment, listed developed country (U.K.) firms are able to finance their growth prospects and tend to improve their vitality. But unlisted developed country (U.K.) firms with limited access to finance may not be able to survive as well as listed developed country (U.K.) firms.

Hypothesis 3a: ECFs' subsidiaries listed in the U.S. have less likelihood of survival than unlisted ECFs' subsidiaries in the U.S.

Hypothesis 3b: DCFs' subsidiaries listed in the U.S. have more likelihood of survival than unlisted DCFs' subsidiaries in the U.S.

\section{Organizational inertia}

There are two dimensions of subsidiary size: one is the absolute size, and the other is the relative size. Absolute size is normally measured by the number of employees, firm revenue, or assets, while relative size is the comparison of the above between a 
subsidiary and the industry average firm size. Prior research has been concentrated almost exclusively on firm absolute size, while neglecting the ways that a firm's scale advantages in comparison to its competitors' may independently define its performance (Bothner, 2005). Thereby, relative size with respect to a firm's competitors is more important than absolute size (Garnier, 1982). Smaller relative sized firms in the market may benefit from a market niche and avoid direct and fierce competition with bigger firms (e.g., Kalafsky, 2004). As discussed above, the organizational practices of ECFs' subsidiaries tend to be unsuitable to the host market of developed countries. ECFs' subsidiaries are striving to shake off the organizational practices that were imprinted by their home institutional environment. So the less original organizational inertia tends to be advantageous for ECFs. Small subsidiaries are flexible and tend to have less organizational inertia (Hannan \& Freeman, 1984) that slows down the process of the adaptation to the new foreign environment. Large subsidiaries with larger organizational inertia and momentum (Hannan \& Freeman, 1984) are inclined to adapt to the new environment more slowly, thus increasing the risk of failure. Larger ECFs' subsidiaries not only face fierce competition, but also create greater threats to local competitors. Thus, the host government tends to pay more attention and provide more scrutiny to them. Thereby, smaller-sized ECFs' subsidiaries tend to have decreased restrictions, fewer uncertainties, and fewer threats from the government. On the other hand, DCFs' subsidiaries come from similarly developed institutional environments and they are more accustomed to withstanding and are able to withstand scrutiny from the government and competitors. DCFs tend to follow the traditional argument that large relative size almost always lowers failure rates (Ranger-Moore, 1997; Hannan \& Freeman, 1984). While 
ECFs tend to oppose the argument, that large relative size tends to raise ECFs' subsidiaries' failure rates. In this case, home country type (ECF or DCF) serves as a moderator in the relationship between relative size and firms' survival. The relationship is positive for DCFs and negative for ECFs. Thus, I propose that,

Hypothesis 4: Home country type moderates the relationship between relative size and firms'survival. That is, the smaller the relative size, the higher the survival rate for ECFs' subsidiaries in the U.S.; the larger the relative size, the higher the survival rate for DCFs' subsidiaries in the U.S.

\section{Different forms of international experience}

International experience has been found to be crucial to international market entry (Delios \& Henisz, 2000; Johanson \& Vahlne, 1977), market exit (Mitchell, Shaver \& Yeung, 1994) and foreign subsidiary performance (Miller \& Eden, 2006). Firms' accumulated international experiences would shape their ways of choosing host countries, corresponding strategies of operating abroad, and survival in their host countries. Furthermore, different forms of international experience may exert different impacts on decision makings. ECFs may have experience of doing business in developing countries, or merely in home countries, or developed countries, or both developing and developed countries. The different forms of experiences may provide ECFs different projections about their future development in host countries. Prior experiences in developed countries are beneficial to firms' survival, because their decision makings and strategies tend more mature and to be tested by the past experience in a similar business environment. Thereby, 
international experience in developed countries tends to be beneficial to both ECFs' and DCFs' subsidiaries' survival in developed markets.

According to Levinthal and March (1993), experiences leave a biased representation of a past reality and tend to mislead the future decision making, given bounded rationality (Simon, 1991). Therefore, ECFs with experiences in developing countries tend to strategize and behave differently from those with experiences in developed countries because various local environments (i.e. strong institutional environment vs. weak institutional environment) cultivate varied ways of doing business. While doing business in the least developing countries, ECFs could transform disadvantages into advantages because they are used to undeveloped institutions with poor regulatory quality and low control of corruption (Cuervo-cazurra \& Genc, 2008). The more successful ECFs are in developing countries, their executives have more confidence in their past decisions and strategies that were made in the past business environment. This could establish an organizational inertia (Hannan \& Freeman, 1984) that makes the ECFs' executives analyze and make decisions in developed markets in the same way as they operate in developed countries. Consequently, their past experiences of operating in developing countries may influence or even mislead their decisions about subsidiaries in developed countries. Hence there are fewer tendencies for ECFs to survive in developed countries when most of the ECFs' strategies and firm structures have evolved from past experiences in developing countries.

On the other hand, DCFs with experience in developing countries together with their prior experiences in developed countries would be able to compare the differences 
between operating in developing and developed countries and thus gain a holistic view on operating in the world. To put it differently, DCFs with experiences in developing countries will obtain a balanced understanding about the two markets; thus, there would be a lower possibility of forming biased cognitions (Thomas, Eden, Hitt, \& Miller, 2007) or being misled since they have relatively more comprehensive and all-around experiences. Therefore, the main effects of ownership, relative size and legal status will be weaker for ECFs with international experiences in developing countries. The main effects will be stronger for firms with international experiences in developed countries and DCFs with international experiences in developing countries. Thereby, I argue that,

Hypothesis 5a: ECFs' operational experiences in developing countries magnify the relationship between ECF subsidiaries' relative size and the likelihood of their survival in the U.S. at both early and later stages of operation.

Hypothesis 5b: ECFs' operational experiences in developing countries attenuate the relationship between ownership and the likelihood of ECFs' subsidiaries' survival in the U.S. at both early and later stages of operation. That is, both state-owned ECFs and private ECFs with operational experiences in developing countries have a lower survival rate than those ECFs with less such experiences.

Hypothesis 5c: DCFs' operational experiences in developing countries positively moderate the relationship between DCF subsidiaries' relative size and the likelihood of their survival in the U.S. 
Hypothesis 5d: ECFs' operational experiences in developed countries negatively moderate the relationship between ECF subsidiaries' relative size and the likelihood of their survival in the U.S.

Hypothesis 5e: ECFs' operational experiences in developed countries strengthen the relationship between ownership and the likelihood of ECFs' subsidiaries' survival in the U.S. at both early and later stages of operation. That is, both state-owned ECFs and private ECFs with operational experiences in developed countries have a higher survival rate than those ECFs with less such experiences.

Hypothesis 5f: DCFs' operational experiences in developed countries positively moderate the relationship between DCF subsidiaries' relative size and the likelihood of their survival in the U.S.

\section{METHODOLOGY}

\section{Sample and statistical method}

The sample is derived from ORBIS (Bureau van Dijk) that records the history and the financial information of (public and private) firms and subsidiaries around the world. The data is complemented by Thomson SDC platinum M\&A database, LexisNexis, Mergent Online, and the U.S. Bureau of Labor Statistics. All the subsidiaries analyzed in

this dissertation operate in the U.S. Their ultimate parents are from either China or U.K. I collected data from ORBIS and examined the survival rate of these subsidiaries that entered the U.S. from 1980 to 2012 in all states in the U.S. 
Because the paper studies survival rates, I used event history analysis in which the unit of analysis is the event history of each firm's exit from the US market, or its acquisition by other firms, bankruptcy, or dissolution. An event history is a longitudinal record of when an event happened to a sample of firms (see Allison, 1984). It is an ideal tool of studying the influential factors of events (Li, 1992). There are two kinds of parametric and nonparametric methods in the event history analysis. Among them, Cox's proportional hazard event history model is the bridge between the two approaches and is described as semi-parametric event history analysis (Allison, 1984). Thus, this paper utilizes Cox's proportional hazard event history model to analyze the time-varying survival rate (Morita, Lee, \& Mowday, 1993). I estimated the models using the STCOX command in STATA 9.0.

\section{Dependent Variable}

Survival. A firm that exists and does not change its ownership is considered "survived" in this paper. To define survival, it is easier to clarify the demise of a firm. According to Freeman, Carroll, and Hannan (1983) and Kalleberg and Leicht (1991), the demise of an organization takes many forms. It includes merger \& acquisition (M\&A), relocation, bankruptcy, and complete dissolution. The longitudinal data I collected can be used to track firms' M\&A activities, bankruptcy, and dissolution. A firm/subsidiary is considered demised (not survived) when two conditions are met. One is that the firm is

not in the list of firms in a certain year and the years after in Orbis. The other condition is that there is the news about its nonexistence (i.e. bankruptcy, dissolution) from LexisNexis, or record of the firms' having been acquired in SDC or Mergent Online. To 
put it differently, data about firms' existence, bankruptcy, dissolution or acquisition in Orbis are double-checked in Thomson SDC, LexisNexis, and Mergent Online. Survival is a dummy variable. " 1 " means the firm survives, " 0 " mean the firm does not survive.

\section{Independent variables}

I measure ownership (state-owned or private) by coding " 1 " if a firm's ultimate parent is state-owned, otherwise " 0 ". Relative size is calculated by the logarithm of the quotient of firm size (FS) and the average industry firm size (AFS). In mathematic symbols, it is described as Log (FS/AFS). I apply the number of employees as a measure of firm size. International experiences are measured by the number of emerging countries and developed countries in which a firms' parent operates. Listed firms are coded as "1" and " 0 " otherwise.

\section{Control variables}

I measure firm absolute size by the number of employees. Industry is classified by the first 3 digit number of a firm's National Industrial Classification System (NAICS) code. Parent age is measured by using 2012 less the year of incorporation or year of the last acquisition if the firm was acquired more than once. Parent size is measured as the number of employees.

The study defines the early stage of operation based on the work of Wilson (2002), who determined the first 5 years as the early stage of a firm' life cycle. 


\section{RESULTS}

Table 1-1 reports the means, standard deviations, and correlations between the major variables used in the analysis. Note that the correlations among the main effects are not problematic. Model 1 in Table 1-2 is the baseline that reports the effects of all control variables. I found that the control variables firm absolute size and parent age add explanatory power to the models. Preceding the tests of the hypotheses, I add the main effects of the country of origin, followed by ownership, legal firm status, and relative size. Model 2 reports the difference between the two groups' survival (DCFs and ECFs) in the window of 32 years $(1980-2012)$. The significant result $\left(\chi^{2}=84.45, \mathrm{P}<0.01\right)$ strongly supports Hypothesis 1, suggesting that DCFs generally have more likelihood of survival than ECFs in the U.S. Inspecting Model 3 and Model 4, I find that state-owned Chinese firms have less chances of survival than private firms in the first five years of operation; while after five years of operation, there is no significant difference between state-owned Chinese firms and private firms in terms of survival rate. This does not comply with hypotheses $2 \mathrm{a}$ and $2 \mathrm{~b}$.

Model 5 and Model 6 test the effect of legal status on the survival of these two types of firms. Model 5 shows that Chinese firms listed in the U.S. are more vulnerable to being acquired or bankruptcy than unlisted Chinese firms, but the legal status has no significant impact on U.K. firms. Therefore, hypothesis $3 \mathrm{a}$ is supported $\left(\chi^{2}=20.61, \mathrm{P}\right.$ $<0.01$ ), but hypothesis $3 \mathrm{~b}$ is not supported. Hypothesis 4 predicts that relative size has the opposite moderating effect on U.K. and Chinese firms' survival. It suggests that U.K. firms with large relative size or Chinese firms with small relative size have more 
likelihood to survive in the U.S. The significant $\left(\chi^{2}=160.60, \mathrm{P}<0.001\right)$ result of Model 7 supports Hypothesis 4 that the greater the U.K. firms' size relative to other firms in the same industry, the more likelihood for U.K. firms to survive in the U.S. While the smaller the Chinese firms are, the greater the chance of survival in the host country.

Hypotheses $5 \mathrm{a}, 5 \mathrm{~b}, 5 \mathrm{c}, 5 \mathrm{~d}, 5 \mathrm{e}$ and $5 \mathrm{f}$ focus on the moderating effects of parent firms' international experience on the U.K. and Chinese firms' survival. Model 8 tests the moderating effect of international experiences on the relationship between the relative size and U.K. firms' survival. The result suggests that international experiences in developed countries strengthen the effect of relative size on U.K. firms' survival, which supports $\left(\chi^{2}=73.12, \mathrm{P}<0.001\right)$ hypothesis $5 \mathrm{f}$. The effect of international experiences in developing countries is not significant in Model 8, so Hypothesis 5c is not supported. Hypotheses $5 \mathrm{a}$ and $5 \mathrm{~b}$ predict the moderating effect of international experiences in developing countries on Chinese firms' survival. Model 9 shows a marginally significant negative rather than positive moderating effect of international experiences in developed countries on Chinese firms' survival in the first 5 years of operation. Model 10 reports a marginally significant $\left(\chi^{2}=36.72, \mathrm{P}<0.1\right)$ moderating effect of international experiences in developed countries on Chinese firms after 5 years of operation, providing marginal support for hypotheses $5 \mathrm{~d}$ and $5 \mathrm{e}$. In other words, the significant negative effect of relative size on Chinese firms' survival decreases when their parent firms have a high level of international experiences in developed countries at their later stage of operation. Thus, Hypotheses $5 \mathrm{~d}$ and $5 \mathrm{e}$ are partially supported, Hypothesis $5 \mathrm{f}$ is supported $\left(\chi^{2}=\right.$ 73.12, $\mathrm{P}<0.01$ ), but Hypotheses 5a, $5 \mathrm{~b}$ and $5 \mathrm{c}$ are not supported. 


\section{DISCUSSION}

This primary purpose of this study was to examine the factors that influence the survival of emerging country (China) firms, compared with the survival of developed country (U.K.) firms in one developed country, the U.S. The study contrasts the factors' different influences on the survival of firms from the emerging country (China) and the developed country (U.K.). This study is perhaps the first to show the survival of emerging country firms in the developed country at the subsidiary level, and report how their survival patterns are different from that of traditional developed country firms. It is imperative for both practitioners and researchers to look into these facts especially when emerging market firms are flocking to foreign countries in an accelerated manner. The paper depicted the trajectory of firms' survival, compared U.K. firms with Chinese firms,

and pointed out factors that impact their survival. New to the present literature, the empirical results support the argument about the firm's relative size, which has an opposite impact on U.K. and Chinese firms' survival. I found that, smaller relative size is beneficial to Chinese firms' survival while bigger relative size harms or threatens their survival; however, U.K. firms with big relative size tend to have longer life. The study also shows that listed Chinese firms tend to have less likelihood to survive than unlisted Chinese firms, but this does not impact U.K. firms' survival. From a practitioner's standpoint, these findings suggest that firms face more vulnerability to survival when having IPO or acquiring listed firms than operating as unlisted firms in the U.S. However, the listed legal form is not a stumbling block for U.K. firms that possess higher invulnerability and get used to the legal and business environment. A counterargument to the impact of listing on ECFs' survival could be that listed ECFs and DCFs have less 
liability of newness and enjoy more financing resources which improve their vitality. Further discussion is needed to probe whether the difficulties and challenges listed ECFs face outweigh the privileges that listed ECFs get in the U.S. stock markets.

The results indicate that developed country (U.K.) firms do have a different survival trajectory from that of emerging country (China) firms in the U.S. I conducted supplemental T-tests on the two groups of firms (U.K. vs. China) in their first 1 through 15 years of operation and found that there is no significant difference between their survival rates in the first 1,2,3,4 years of operation. However, these two groups of firms grow differently from their 5th year and the years after. Figure 1-2 shows the Kaplan-Meier survival estimates on U.K. and Chinese firms' survival in the 32 years of observation (1980-2012). This graph supports the T-test by illustrating that Chinese and U.K. firms have a similar survival rate in their first 5 years of operation, but then, U.K. firms have significant stronger vitality to survive persistently than Chinese firms from the 6th years of the operation and the years after. This very interesting observation is worth continuous attention. It is worth mentioning that the empirical data partitions the two stages of U.K. and Chinese firms' operation in the U.S, based on the significant difference between their survival rates across years. So it is interesting to explore whether the fifth year of operation is a threshold for Chinese firms, or for other emerging country firms operating in developed countries. Also, this result has implications for practitioners that strategizing the late stage of an operation helps improve a firm's vitality. Another interesting finding is that international experiences in the two types of countries exert different influences on firms' survival. International experiences in developing countries 
and developed countries pose different influences on firms' survival in the U.S. I argue and found that the impact of relative size and ownership on firms' survival becomes greater when parent firms have more international experiences in developed countries, but international experiences in developing countries do not have significant moderating effect, as indicated in the empirical result. Another key finding is that, international experiences in developing countries do not appear to impact Chinese firms' survival in the U.S. I also found that international experiences in developed countries have a significant moderating effect on the relationship between the ownership of Chinese firms and their survival at the early stage of operation. But such international experiences' impact diminishes at the late stage for state-owned Chinese firms.

\section{CONCLUSION}

I hope that this study has contributed to the current literature on emerging market firms by taking the first step toward examining how an emerging country firm survives in a developed country and avoids drowning in the developed country, and how differently DCFs and ECFs survive in a developed country. The empirical study suggests that emerging country firms do not survive as "easily" as developed country firms, particularly after 5 years of operation, when it becomes difficult for emerging country firms to secure a foothold in the developed country market. Listed emerging country firms have less likelihood of survival than unlisted ones. A large relative size in the industry does not always mean power or market share. It is associated with smaller chances of survival for emerging country firms, but predicts the longevity of developed country firms. The findings also show that international experiences in developed 
countries strengthen the positive relationship between relative size and DCFs' survival, while such international experiences aggregates the negative relationship between relative size and ECFs' survival. ECFs that have affluent international experiences in other emerging markets will not help them overcome the threats of the demise in developed countries. Such experience would not improve DCFs' survival rate in the U.S. neither.

While there are numerous studies in the emerging market literature aimed at explaining why and how they go abroad, there are many fewer studies of how these firms survive in developed countries whose environments are quite distinguished from their home countries. I hope this study fills this gap by looking at their survival trajectory comparing with developed country firms operating in the same market. The study focuses on basic influential factors including relative size, legal status, ownership, and international experiences in developed or developing countries, all of which exert interestingly different impacts on both types of firms. I also hope these findings enrich the current literature on survival strategy and spur further investigation based on more years of observation and more countries in the sample. While this study primarily focuses on the emerging country firms' survival within developed countries, I also hope to provide implications for the literature on organizational ecology, where the relationship between organizations' demographics and survival has been frequently discussed.

By offering the empirical analysis of firms' survival, I view the study as having practical implications for both emerging country firms and developed country firms that may be competitors in the same market. Developed country firms generally have 
advantages of survival, especially after 5 years of operation; that is, they have a higher level of vitality than emerging country firms. Emerging country firms need to manage well the relationship between their legal status, relative size in industry and survival. In the meantime, international experiences in other developing countries do not benefit their operation in developed countries. However, their parent firm's experiences in developed countries do help them strengthen their life force in developed countries.

\section{LIMITATIONS AND FUTURE RESEARCH}

This study has several limitations. Firstly, the sample is limited to only one emerging country and one developed country. Further investigation on more countries is needed. This study is an initial study primarily focusing on the relationship between survival and subsidiaries' demographic information, including relative size, ownership, legal status, and international experiences. If more information about subsidiaries' R\&D capability, firm structure, and board information is available, there might be more interesting findings and deeper understanding about the emerging country firms' survival and growth. Second, one of the measures of survival in this paper is based on ownership change. Researchers may argue that the firm still survived after it changed the ownership (acquisition). This is in line with the work of Freeman, Carroll, and Hannan (1983) and Kalleberg and Leicht (1991). Together with acquisition, other forms of demise are relocation, bankruptcy, and complete dissolution. Further study is needed to probe the different forms of demise and the definition of firm survival. Third, the industry is still a control variable and the measure is the first 3 digits of the National American Industry Classification System (NAICS) code. A concern is that the impact of the industry would 
be better captured if there is a measure of industry sensibility to national security available. This measure is relevant to emerging country firms that tend to be questioned threats to national security when its industry is rather sensitive. Fourth, I use the number of employees to measure the firm's absolute size, overlooking variations in the revenue and market shares. If information about sales and market shares of subsidiaries is available, a better approach could be weighted sales or market share by the number of employees. Despite the foregoing limitations, I see the study as improving our understanding of the survival of the emerging country firms in developed countries. Beyond the scope of the present study, I propose extensions for the future research. For instance, we should explore the relationship between the emerging market firms' structure, R\&D capacity, board structure, top management team composition and survival. A comparison of the ECF survivors and failures is also meaningful and interesting. Given the increasing importance of the emerging country's economic role in the global market and more affluent data of emerging country firms available, I believe that additional research on comparison of survived and dead ECFs, ECFs' operational difficulties in host countries, and ECFs' survival strategies would represent valuable contributions to both the literature and practices of international business. 
Figure 1-1 Essay 1 model

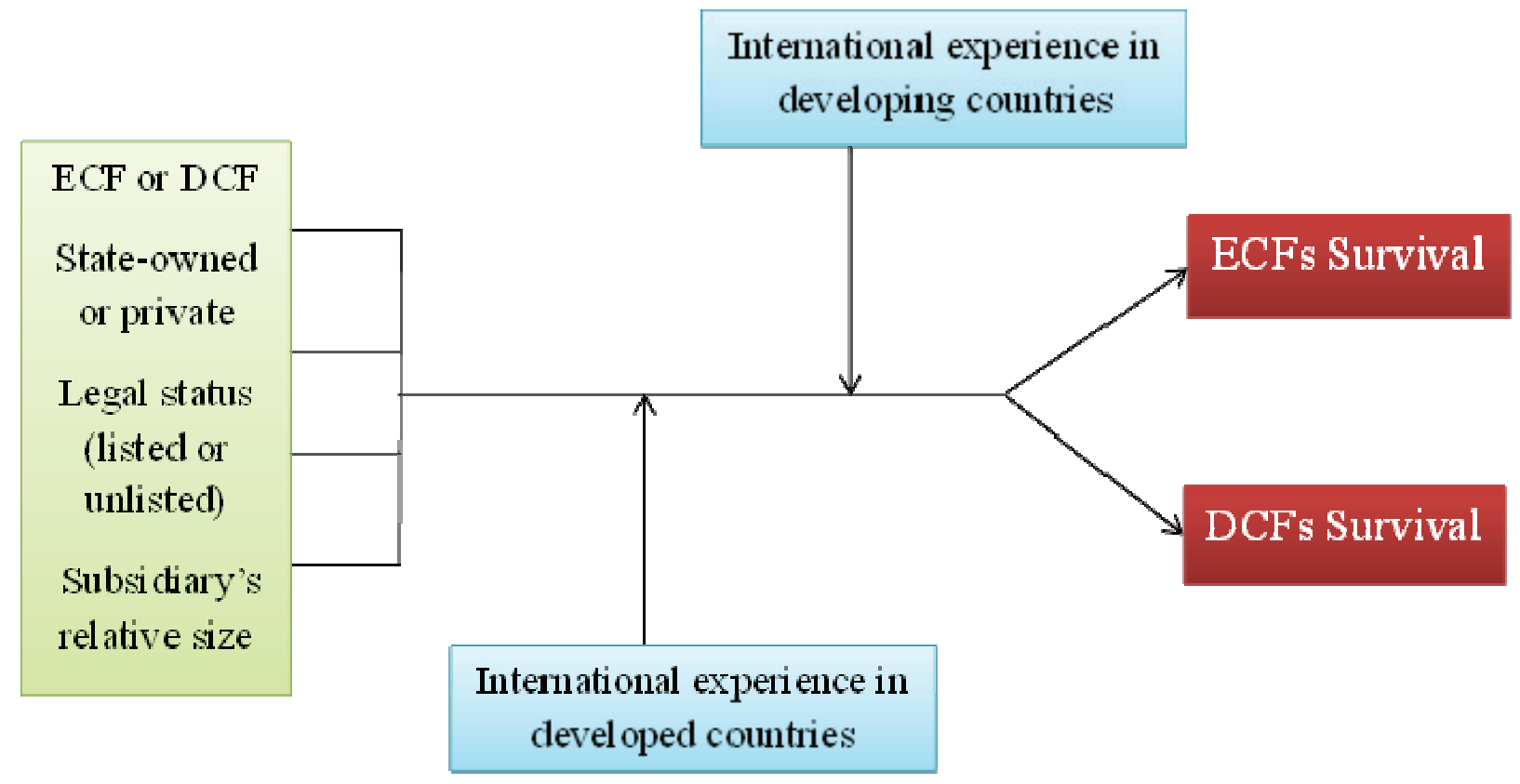

Figure 1-1 Survival trajectory of U.K. firms (group 0) and China (group 1)

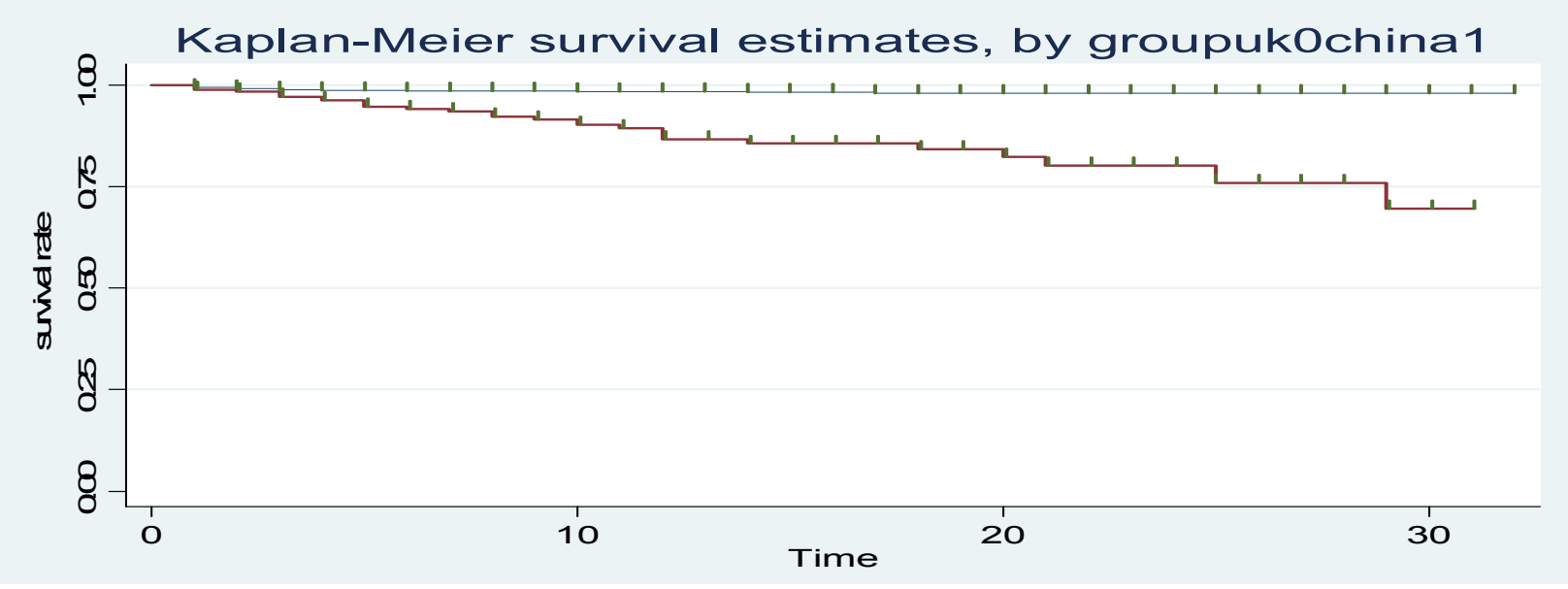

$$
\text { Group }=0 \text { U.K. firms }
$$

$$
\text { Group }=1 \text { China firms }
$$


Table 1-1 Correlation matrix

\begin{tabular}{|c|c|c|c|c|c|c|c|c|c|c|c|}
\hline & Mean & Std. dev. & 1 & 2 & 3 & 4 & 5 & 6 & 7 & 8 & 9 \\
\hline 1. Firm absolute size & 3280.609 & 30682.640 & 1.00 & & & & & & & & \\
\hline 2. Legal status & 0.1092437 & 0.313 & 0.29 & 1.00 & & & & & & & \\
\hline 3. Parent size & 13952.03 & 75985.050 & 0.02 & -0.02 & 1.00 & & & & & & \\
\hline 4. $\quad$ Parent age & 61.836 & 256.700 & -0.00 & 0.07 & -0.02 & 1.00 & & & & & \\
\hline 5. Intl experience in Developed countries & 7.731 & 19.431 & 0.00 & -0.11 & 0.10 & -0.04 & 1.00 & & & & \\
\hline 6. Intl experience in Developing countries & 3.487 & 6.242 & 0.22 & 0.00 & 0.05 & -0.04 & 0.68 & 1.00 & & & \\
\hline 7. Industry & 424.378 & 113.048 & -0.08 & -0.16 & -0.09 & -0.01 & 0.12 & 0.07 & 1.00 & & \\
\hline 8. Ownership & 0.336 & 0.473 & -0.07 & -0.22 & 0.13 & -0.06 & 0.15 & 0.2 & 0.12 & 1.00 & \\
\hline 9. $\quad$ Firm relative size & -0.162 & 0.972 & 0.40 & 0.38 & -0.03 & 0.06 & 0.12 & 0.20 & 0.00 & -0.02 & 1.00 \\
\hline
\end{tabular}


Table 1-2 Survival of DCF/ECF subsidiaries in the US

\begin{tabular}{|c|c|c|c|c|c|c|c|c|c|c|}
\hline & Model 1 & $\begin{array}{l}\text { Model } 2 \\
\text { (H1) }\end{array}$ & $\begin{array}{l}\text { Model } 3 \\
\text { (H2a) }\end{array}$ & $\begin{array}{l}\text { Model } 4 \\
\text { (H2b) }\end{array}$ & $\begin{array}{l}\text { Model } 5 \\
\text { (H3a) }\end{array}$ & $\begin{array}{l}\text { Model } 6 \\
\text { (H3b) }\end{array}$ & $\begin{array}{l}\text { Model } 7 \\
\text { (H4) }\end{array}$ & $\begin{array}{l}\text { Model } 8 \\
\text { (H5c \& 5f) }\end{array}$ & $\begin{array}{l}\text { Model } 9 \\
(\mathrm{H} 5 \mathrm{a}, 5 \mathrm{~b}, 5 \mathrm{~d}, \\
\& 5 \mathrm{e})\end{array}$ & $\begin{array}{l}\text { Model } 10 \\
(\mathrm{H} 5 \mathrm{a}, \\
\text { 5b,5d,\& 5e) }\end{array}$ \\
\hline $\begin{array}{l}\text { Firm absolute } \\
\text { size }\end{array}$ & $\begin{array}{l}-.000013 * * * \\
(2.25 \mathrm{e}-06)\end{array}$ & $\begin{array}{c}-.0000 * * * \\
(2.34 \mathrm{e}-06)\end{array}$ & $\begin{array}{l}.0008 \\
(.0010) \\
\end{array}$ & $\begin{array}{l}-.00003 \dagger \\
(.0003)\end{array}$ & $\begin{array}{l}.0002 \\
(.000358)\end{array}$ & $\begin{array}{l}1.53 \mathrm{e}-06 \\
(2.53 \mathrm{e}-06)\end{array}$ & & & & \\
\hline Industry & $\begin{array}{l}-.0008 \\
(.0012) \\
\end{array}$ & $\begin{array}{l}-.0002924 \\
(.00130) \\
\end{array}$ & $\begin{array}{l}-.00134 \\
(.0020) \\
\end{array}$ & $\begin{array}{l}-.0003 \\
(.0032) \\
\end{array}$ & $\begin{array}{l}-.0025 \\
(.0016) \\
\end{array}$ & $\begin{array}{l}.0033 \\
(.0021) \\
\end{array}$ & $\begin{array}{r}-.0005 \\
(.0011) \\
\end{array}$ & $\begin{array}{l}.0013 \\
(.0027) \\
\end{array}$ & $\begin{array}{l}-.0012 \\
(.0027) \\
\end{array}$ & $\begin{array}{l}-.0008 \\
(.0028) \\
\end{array}$ \\
\hline Parent age & $\begin{array}{l}.0089 \dagger \\
(.0047)\end{array}$ & $\begin{array}{l}.0024082 \\
(.00452)\end{array}$ & $\begin{array}{l}.0167 \\
(.0130)\end{array}$ & $\begin{array}{l}.0144 \\
(.0142)\end{array}$ & $\begin{array}{l}.0161 \\
(.0104)\end{array}$ & $\begin{array}{l}.0108 \\
(.0089)\end{array}$ & $\begin{array}{l}.0015 \\
(.0019)\end{array}$ & $\begin{array}{l}-.0162 * \\
(.0069)\end{array}$ & $\begin{array}{l}.0123 \\
(.0250)\end{array}$ & $\begin{array}{l}.0373 \dagger \\
(.0209)\end{array}$ \\
\hline Parent size & $\begin{array}{l}1.05 \mathrm{e}-06 \\
(1.76 \mathrm{e}-06)\end{array}$ & $\begin{array}{r}-1.16 \mathrm{e}-06 \\
(1.16 \mathrm{e}-06) \\
\end{array}$ & $\begin{array}{l}4.10 \mathrm{e}-06 \\
(6.16 \mathrm{e}-06)\end{array}$ & $\begin{array}{l}-2.85 \mathrm{e}-06 \\
(1.27 \mathrm{e}-06) \\
\end{array}$ & $\begin{array}{l}-2.06 \mathrm{e}-06^{*} \\
(1.06 \mathrm{e}-06)\end{array}$ & $\begin{array}{l}3.76 \mathrm{e}-06 \\
(1.63 \mathrm{e}-07)\end{array}$ & $\begin{array}{l}-1.80 \mathrm{e}-06 \\
(1.22 \mathrm{e}-06) \\
\end{array}$ & $\begin{array}{l}-2.03 \mathrm{e}-06 \\
(.00001) \\
\end{array}$ & $\begin{array}{l}7.47 \mathrm{e}-07 \\
(9.39 \mathrm{e}-06) \\
\end{array}$ & $\begin{array}{l}-6.22 \mathrm{e}-06 \\
(4.35 \mathrm{e}-06) \\
\end{array}$ \\
\hline $\begin{array}{l}\text { DCF/ECF } \\
\text { membership }\end{array}$ & & $\begin{array}{l}-2.7788^{* * *} \\
(.3587) \\
\end{array}$ & & & & & $\begin{array}{l}-2.6726 * * * \\
(.4971) \\
\end{array}$ & & & \\
\hline $\begin{array}{l}\text { State-owned } \\
\text { dummy }\end{array}$ & & & $\begin{array}{l}-2.1338 * * * \\
(.662)\end{array}$ & $\begin{array}{l}.2285 \\
(.600)\end{array}$ & $\begin{array}{l}-.9078^{*} \\
(.4425)\end{array}$ & & & & $\begin{array}{l}1.0391 \\
(1.9105) \\
\end{array}$ & $\begin{array}{l}-.7538 \\
(1.3558)\end{array}$ \\
\hline Listed/Unlisted & & & & & $\begin{array}{l}-2.0368^{* * * *} \\
(.5050)\end{array}$ & $\begin{array}{l}-111.294 \\
(.)\end{array}$ & $\begin{array}{l}-3.2573 * * * \\
(.3464)\end{array}$ & $\begin{array}{l}-0.0786 \\
(.)\end{array}$ & $\begin{array}{l}-3.1985^{* *} \\
(1.3061) \\
\end{array}$ & $\begin{array}{l}-1.9049 * * \\
(.6397)\end{array}$ \\
\hline Relative size & & & & & & & $\begin{array}{l}-.7651 * * * \\
(.2784)\end{array}$ & $\begin{array}{l}-.9431 * * \\
(.3369) \\
\end{array}$ & $\begin{array}{l}.7908 \\
(.7801)\end{array}$ & $\begin{array}{l}-.1019 \\
(.7985) \\
\end{array}$ \\
\hline $\begin{array}{l}\text { membership * } \\
\text { relative size }\end{array}$ & & & & & & & $\begin{array}{l}.9633 * * * \\
(.2845)\end{array}$ & & & \\
\hline Developing Exp. & & & & & & & & $\begin{array}{l}-.2184 \dagger \\
(.1150) \\
\end{array}$ & $\begin{array}{l}.3327 \\
(.4551) \\
\end{array}$ & $\begin{array}{l}.3078 \\
(.3512) \\
\end{array}$ \\
\hline Developed Exp. & & & & & & & & $\begin{array}{l}.3865^{* *} \\
(.1510)\end{array}$ & $\begin{array}{l}.1689 \\
(.6151) \\
\end{array}$ & $\begin{array}{l}1.1196 \dagger \\
(.6100)\end{array}$ \\
\hline $\begin{array}{l}\text { Developing Exp. } \\
\text { * relative size }\end{array}$ & & & & & & & & $\begin{array}{l}.0689 \\
(.0534) \\
\end{array}$ & $\begin{array}{l}.1816 \\
(.14533) \\
\end{array}$ & $\begin{array}{l}-.6971 \\
(.6095) \\
\end{array}$ \\
\hline $\begin{array}{l}\text { Developed Exp. } \\
\text { relative size }\end{array}$ & & & & & & & & $\begin{array}{l}-.0879 \dagger \\
(.0514)\end{array}$ & $\begin{array}{l}.9700 \dagger \\
(.5219) \\
\end{array}$ & $\begin{array}{l}1.2000 \dagger \\
(.6261)\end{array}$ \\
\hline $\begin{array}{l}\text { Developing Exp. } \\
\text { * ownership }\end{array}$ & & & & & & & & & $\begin{array}{l}.0205 \\
(.4474) \\
\end{array}$ & $\begin{array}{l}.1105 \\
(.3924) \\
\end{array}$ \\
\hline $\begin{array}{l}\text { Developed Exp. } \\
\text { ownership }\end{array}$ & & & & & & & & & $\begin{array}{l}-1.7176 \dagger \\
(1.0552)\end{array}$ & $\begin{array}{l}.0222 \\
(.9187) \\
\end{array}$ \\
\hline Observations & 1292 & 1292 & 93 & 131 & 224 & 1068 & 1292 & 1068 & 93 & 131 \\
\hline log-likelihood & -284.21 & -250.07 & -44.0 & -64.72 & -125.47 & -27.63 & -212.79 & -59.70 & -33.21 & -54.49 \\
\hline $\begin{array}{l}\text { Model Chi- } \\
\text { squared }\end{array}$ & $17.80 * * *$ & $84.45 * * *$ & $11.77^{*}$ & 6.41 & $20.61 * *$ & 137.25 & $160.60 * * *$ & $73.12 * * *$ & $25.24 * *$ & $36.72 * * *$ \\
\hline
\end{tabular}

$\dagger \mathbf{P}<0.1 \quad * \mathbf{P}<0.05 \quad * * \mathbf{P}<0.01 \quad * * * \mathbf{P}<0.001$ 


\title{
ESSAY 2. Global orientation and emerging country (China) firms' survival in the
} U.S.

\begin{abstract}
Emerging country firms (ECFs) have undergone failures in developed countries partially resulting from the imprinting effects of their home countries' institutions on their operation in foreign markets. Thus, ECFs are trying to absorb advanced knowledge about operations in foreign markets by hiring executives with international backgrounds and participating in global organizations or alliances, defined as global orientation in this paper. The paper further tests the association of this global orientation with ECFs subsidiaries' survival in the United States. The results mainly support the arguments that global orientation is not always good for ECFs subsidiaries' survival if overemphasizing the top management team's international educational background.
\end{abstract}

Key words: global orientation, global mindset, survival, UNGC, emerging country firms 


\section{INTRODUCTION}

The boosting of emerging markets and emerging multinationals has gained tremendous attention from scholars and practitioners. Many studies examined the strength of ECFs and their new strategies, which are different from traditional multinational Corporations (MNCs). Meanwhile, relatively little attention is paid to the failures of ECFs in developed and developing countries. The divestiture and the bankruptcy of ECFs operating in host countries have shown that the advanced institutional environment is critical, and it is not easy to keep their foothold in foreign markets, at least for the first few years of operation. It is reported that Chinese companies that obtained listings on U.S. stock exchanges within the past few years are increasingly exiting the market (USA Today). One of the main reasons is that these firms were not able to get used to the new country's environment including political, financial, and legal, or to the foreign language. Their strategic decision-making tends to be greatly influenced by their home country's culture and institutions; due to the "shadow of the past" their mindsets and routines have been shaped by their past experiences and become part of their DNA (Madhok \& Keyhani, 2012). Since the internationalization of most ECFs is at a relatively early stage, it tends to take firms a long time to gain the experiences and knowledge needed to help them adapt to the local institutional and economic environment and to survive in host countries.

With this motivation, ECFs in developed countries tend to hire more executives with international backgrounds and affiliated with global organizations or alliances. These two internal preparations and external actions tend to activate ECFs' absorption of new knowledge and diverse perspectives in decision making for operation in foreign 
markets (Huber, 1991; Winter, 2000). This phenomenon is defined as global orientation in this paper. Based on the definition of global orientation, I further tests the impact of this orientation on ECFs subsidiaries' survival. The moderating effect of industry globalization is discussed.

The paper offers contributions to the literature on global mindsets. It tries to enrich the literature on global mindsets at the organizational level, which is under limited exploration. Further, the paper contributes to the literature on survival, particularly in the emerging market context by linking survival with ECFs' global orientation. Consequently, it offers empirical implications for ECFs operating in foreign markets. The results show that international work experiences and the proportion of foreign executives are favorable to ECFs' survival.

\section{THEORY AND HYPOTHESES}

\section{Emerging country firms' global orientation}

It is widely recognized that emerging markets were blocked for a long period of history before these countries opened and linked up with the global market by privatization and deregulation. Firms from emerging markets are unfamiliar with the outside international market, and tend to think and make decisions based on their home country's criteria and standards rather than from multiple perspectives. But ECFs have chances of interacting with foreign country firms at home due to emerging markets' open market policies. Their alliance experiences with developed country firms in domestic markets increase the likelihood of entry into a developed country, but decrease the likelihood of survival resulting from cognitive biases (Thomas, Eden, Hitt \& Miller, 2007). A cognitive bias indicates that the ECFs' executives may be inappropriately 
confident based on prior alliance experiences with developed market firms when ECFs were operating in developed countries. This fact brings up the importance of executives' having a global mindset when pursuing global-oriented strategies. In other words, ECFs need to be familiar with and adequately exposed to the international market. Specifically speaking, the top management team (TMT) needs to be aware of the international market and global standards and to make decisions from a global perspective embracing multiple perspectives. Meanwhile, ECFs need to get involved in international organizations and global-oriented activities, all of which indicate a corporate global orientation. The paper defines corporate global orientation in two facets. One facet is internal, based on TMT composition, and the other is external, based on realized practice. Both the internal and external factors intensify a firm's efforts to seek external knowledge (Huber, 1991; Winter, 2000) of the operation and sustainable competitive advantage in foreign markets. Therefore, global orientation refers to the ECFs' propensity to establish management teams with global mindsets and to participate in global-oriented activities, all for the purpose of absorbing knowledge regarding operating in foreign markets and mitigating the imprinting effect of their home countries' institutions on their global operations.

The paper proposes two dimensions of global orientation, TMT's international composition and firms' global-oriented practices. A TMT's international composition refers to the team's collective international education and working background, which reflects the TMT's global mindset. Global mindset is associated with demographic and background characteristics (Arora, Jaju, Kefalas, \& Perenich, 2004). At the firm level, the awareness and willingness to think and act with a global mindset could be manifested by a TMT's international composition, meaning the demographic diversification of the 
members in the TMT. A TMT's international composition could bring in diverse perspectives for decision making. Arora et al. (2004) argue that TMT demographic and background characteristics, such as education, working experience, age, and gender, are associated with a global mindset. Carpenter and Fredrickson (2001) proposed an inverted U-shaped relationship between the TMT's international experience and the expansiveness of its firm's global strategic posture. They also predicted an inverted U-shaped relationship between executives' educational heterogeneity and the expansiveness of their firm's global strategic posture. This paper predicts that the more international experiences the TMT has, the more likelihood that teams have higher awareness of opinions from multiple standpoints and cultural backgrounds that are relevant to the foreign markets.

Global-oriented practices are the actions an ECF takes to realize the global mindset of the TMT members. Levy (2005) found that a TMT considering the external environment and a diverse set of elements in this environment is more likely to develop an expansive global strategic posture. Perlmutter (1969) emphasized that firms with a geocentric mindset have "a greater sense of commitment to worldwide objectives". Therefore, these practices include activities promoting corporate social responsibility (Paul, Meyskens, \& Robbins, 2011), such as joining the United Nation Global Compact (UNGC), or Global Reporting Initiatives (GRI).

\section{Global-oriented practices}

A TMT international background shows the firm's willingness to embrace a global mindset, and practices with global consideration display a firm's ability to realize a global orientation. For instance, UNGC was initiated by the United Nations to promote 
global economic development, in ways perceived to be beneficial to society (Waddock, 2004). The UNGC's ten principles revolve around four topics: human rights, labor standards, environment, and anti-corruption. Firms that adopt the UNGC are expected to provide leadership in promoting these ten principles. As a side benefit, affiliation also establishes a positive reputation for multinational firms (MNEs) joining the UNGC (Janney, Dess, \& Forlani, 2009). By joining global organizations or alliances, ECFs are able to build up a network at the level of the global market (Janney et al., 2009), increasing the interactions between ECFs and other foreign firms. Consequently, they are exposed to new external knowledge during the interaction with other foreign firms. These external sources of knowledge and experience activate firms' absorptive capacity (Vermeulen \& Barkema, 2001; Zahra \& George, 2002), which capacity may lead to competitive advantages (Zahra \& George, 2002), and thus, greater likelihood of survival. So the global-oriented practices should be positively associated with ECFs' survival.

Hypothesis 1: The global-oriented practices of an ECF are positively associated with the ECF subsidiaries' survival in developed countries.

\section{TMT international background}

The survival of an organization is contingent upon how it deals with sources of uncertainty. So it is important to have individuals who are able to reduce uncertainties. Upper echelon perspective stresses that firms' decision making is based on top executives' values, powers, mindset, and demographic characteristics such as age, career experiences, formal education, and socioeconomic background (Hambrick \& Mason, 1984). It is documented that executives with a global mindset have a high level of cognitive 
capabilities, particularly scanning and information-processing capabilities and balancing competing realities and demands (Rhinesmith, 1992). They tend to strategize from diverse perspectives that are more relevant to foreign markets, and take appropriate measures to analyze and handle varied issues in the host country.

Arora et al. (2004) found that a set of individual background characteristics are positively related to the global mindset, and include training in international management, foreign country living experience and job experience, and family members of foreign origin. TMT members who have international working, studying or living experiences tend to embrace multiple perspectives while analyzing problems and making decisions. ECFs are relatively young to the international market and need more insight and deeper understanding of the developed country market and the institutional environment. TMT members with a higher degree of international composition more likely understand local needs and the institutional environment. And consequently, there is more possibility that the TMT members are able to make appropriate decisions based on holistic views that minimize the possibilities of failures.

The TMT's international background generally includes international education, international work experiences, and foreign nationality (Arora et al. 2004). These three components have influences on ECFs' attributes and roles in triggering absorptive capacity.

Internationalized business faces a more complex customer environment than a domestic firm. A common requirement is that potential CEOs should be genuinely bilingual and multicultural (Oxelheim \& Randoy, 2005). International education refers to the education executives received from countries other than their home country. Greater 
international educational experience among TMT typically provides the TMT with a greater awareness of international opportunities and the credibility with the board and other stakeholders regarding those opportunities, thereby providing management with more degrees of freedom in managing the complexities of global multimarket competition (Carpenter, Pollock, \& Leary, 2003).

International work experience is hands-on experience that is directly obtained from real-world management in the foreign market. It is a crucial factor in outstanding performance (McEnrue, 1988) and is favorable to multinational activity (Sambharya, 1996; Shrader, Oviatt, \& McDougall, 2000). Moreover, more work experiences bring more linkages between executives and the foreign market. International work experience can be well-absorbed in the absorption process and activate firms' absorptive capacity, which in turn improve the possibility of obtaining sustainable competitive capacity (Zahra \& George, 2002) and thus survival. Thus, TMT international work experience positively influences firm survival.

Furthermore, foreign executives are inclined to have more multiple standpoints than native executives, and retain more linkages with the foreign market. Each executive has unique sets of human and social capital assets such as education, expertise, skills, access, and an individualized set of contacts (Ameer, Ramli, \& Zakaria, 2010). The experience and assets increase the chances of success in international markets (e.g., Smith, Peterson, \& Wang, 1996). Foreign executives' diverse perspectives are conductive to firms' efforts to seek and captivate knowledge from the external environment, and gain sustained competitive advantage and success. Plus, foreign executives' diverse perspectives and mindset are also useful in recognizing and capturing new opportunities 
and building beneficial linkages in foreign markets (Zahra \& George, 2002), thereby improving the odds of survival.

Consequently, the paper proposes,

Hypothesis 2a: The more international education background TMT members have, the more likelihood that ECFs survive in the U.S.

Hypothesis 2b: The more international work background TMT members have, the more likelihood that ECFs survive in the U.S.

Hypothesis 2c: The more foreigners in the TMT, the more likelihood that the ECF survive in the U.S.

\section{Moderating effect of industry}

Industry's degree of globalization. Industry factors impact firms' survival in significant ways (Porter, 1980; Shepherd \& Douglas, 2000). International industries vary along a spectrum from multi-domestic to global in their competitive scope. It is a series of linked domestic industries in which the rivals compete against each other on a truly worldwide basis (Porter, 1986). International competition creates the need for firms to distribute and coordinate value-added activities they perform across multiple countries, which is commonly termed global integration (Bartlett \& Ghoshal, 1989; Dunning, 1980). Such an integration process includes both intangible and tangible transfers. A higher degree of global integration indicates a higher level of intangible and tangible transfers across countries. The transfers bring standardized norms, industrial codes, and industrial regulations worldwide. Both tangible and intangible transfers consequently improve individual firms' connection and adaptation to the global market, and decrease the 
imperative necessity of bearing global orientation in a certain industry. Moreover, ECFs from a highly internationalized industry have more chances of exposure to foreign partners and global markets, and more opportunities to experience balancing multiple perspectives. Thus, it will intensify the relationship between purposely establishing global orientation and survival.

Hypothesis 3a: The relationship between global-oriented practice and ECF subsidiaries' survival is stronger for an ECF in an industry with a high level of globalization.

Hypothesis 3b: The relationship between TMT members' international education background and ECF subsidiaries' survival is stronger for an ECF in an industry with a high level of globalization.

Hypothesis 3c: The relationship between TMT members' international work experiences and ECF subsidiaries' survival is stronger for an ECF in an industry with a high level of globalization.

Hypothesis 3d: The relationship between TMT percentage of foreigners and ECF subsidiaries' survival is stronger for an ECF in an industry with a high level of globalization.

\section{SAMPLE, METHOD AND MEASURES}

The list of Chinese subsidiaries is sampled from Orbis. All of them operate in the U.S. TMT information is obtained from Orbis, Bloomberg Business Week, Lexis/Nexis, firms' annual reports and official websites. The list of UNGC participants is collected from the UNGC website. The paper applies Weibull survival analysis to analyze the timevarying survival rate. Weibull analysis is used because it is appropriate for a relatively 
small sample of failure (Abernethy, 2006) and it is superior in both generality and parsimony (Hannan \& Freeman, 1989). There are 115 cases in the sample, and among them, 19 firms had failed. Thus, Weibull is a reliable method for capturing the influential factors on firms' survival.

\section{Dependent variable}

Survival. A firm that exists and does not change its ownership is considered survived in this paper. According to Freeman, Carroll, and Hannan (1983) and Kalleberg \& Leicht (1991), the demise of an organization takes many forms. It includes merger \& acquisition (M\&A), relocation, bankruptcy, and complete dissolution. The data I have can track firms' M\&A activities, bankruptcy, and dissolution. A firm/subsidiary is considered demised (not survived) when two conditions are met. First, a firm is not in the list of firms in a certain year and the years after in Orbis. Second, there is news about its nonexistence (i.e. bankruptcy, dissolution) from LexisNexis, or record of being acquired in SDC or the record in Mergent Online. To put it differently, data about firms' existence, bankruptcy, being acquired or dissolved in Orbis are double-checked in Thomson SDC, LexisNexis, or Mergent Online. Survived firms are coded as 1, otherwise 0. 


\section{Independent variables}

TMT International work experience. Following the prior research (e.g., Shrader et al., 2000; Mudambi \&Zahra, 2007), I measured TMT international work experience by averaging the total years of international work experience of the firm's TMT.

TMT International education. Similar to TMT international work experience, TMT education experience is calculated by TMT's average years of college education outside China. The undergraduate degree is recorded as 4 years of education, the master's is considered 2 years of education, and the Ph.D. 5 years.

TMT percentage of foreigners. It is measured as the percentages of individuals whose nationalities are not Chinese.

UNGC participation. This is a dummy variable. Each firm in the sample is checked in the list of UNGC participants on the UNGC website. Participants are coded as 1 , otherwise 0 .

\section{Moderator}

Industry Globalization (IG). I use the standard Grubel and Lloyd Index of Intraindustry Trade (IIT) to capture industry globalization (Greenaway \& Milner 1986; Grubel \& Lloyd, 1975; Hassan, 1987; Makhija, Kim, \& Williamson, 1997). It measures the extent to which an industry's various value-added activities are globally integrated. This index measures the extent of the absolute amount of exports in a certain industry which amount is offset by imports in the same industry, and expresses this intra-industry trade (IIT) as a proportion of the total trade in this industry. By definition, IIT lies between zero and one, with zero indicating no intra-industry trade and one indicating "complete" 
intra-industry trade. There are 31 types of intra-trade between China and the U.S. in the sample. It ranges from mining, oil, chemicals, pharmaceuticals, iron and steel, machinery, and electronic equipment, to transportation, construction, financial services, computer and information services, communication, and cultural and educational services.

\section{Controls}

Firm size, ownership (state-owned or private), organization structure (listed or unlisted), industry, parent international experience, and parent age are controlled. Firm size has important implications for survival (Audretsch, 1995; Hannan \& Freeman, 1977). Big firms have large inertia and slack resources able to buffer the threats of failure, and thus increase the firms' odds of survival. In China, state-owned firms receive more government support than private firms. Firms with government support are better positioned than their rivals to get over the liability of newness (Mudambi, 1998). Voluntary disclosures are more favorable to listed firms from countries with stronger legal institutions (Shi, Magnan, \& Kim, 2012). Emerging markets are characterized as having weak institutions and under-developed legal system (Cuervo-cazurra \& Genc, 2008). Thus, US-listed ECFs face more pressure and scrutiny than unlisted ECFs and less odds of survival. The stock markets are limited to US stock markets (New York Exchange, NASDQ, and American Stock Exchange). Listed firms are coded as 1, otherwise 0 . The industry is captured by the first three-digit number of a firm's National Industrial Classification System (NAICS). Parent age is measured by years of operation in the home country since its incorporation. International experience is measured by the number of countries a firm's parent operated in since inception. The researcher predicts 
that parent international experiences enable the firms to receive experiences and relatively mature international strategies and organizational practices, and management teams have more chances of learning about the challenges associated with different strategic decisions in developed countries (Mitchell, 1994).

\section{RESULTS}

Table 2-1 reports the means, standard deviations, and correlations between the variables in the analysis. Inspecting the descriptive statistics, the variables have low correlations ranging from -0.0008 to 0.5336 , all of which are below 0.70 (see Tabachnick \& Fidell, 2007). The mean variance inflation factor (VIF) is 1.43; the highest VIF is 1.68 , far below the commonly used cut-point of 10 (Hair, Anderson, Tatham, \& Black, 1998). This shows that there is no multicollinearity problem in the analysis.

I used the Weibull Analysis to estimate the influence of global orientation on firms' survival. Table 2-2 presents the results from the survival analyses. Model 1 is the baseline that shows the effects of the control variables. The positive coefficient of firm size indicates firm size is positively associated with survival. The model also shows the significant influence of organization form and ownership on survival. Organization form is a dummy variable, with 1 representing listed firms and 0 unlisted firms. In line with the prediction, the negative and significant coefficient implies listed firms have fewer chance of survival. Ownership is also a dummy variable. State-owned firms are coded as 1, while private firms 0 . The significant negative coefficient of ownership shows that state-owned firms have less likelihood of survival, which is the opposite of the prediction.

I first test Hypothesis 1, which suggested that firms that joined UNGC have more likelihood to survive. Model 2 shows the result is not significant, and thus, hypothesis 1 
is not supported. To test Hypothesis 2a, I add the effect of TMT international education in Model 3. Model 3 indicates TMT international education has a significant $\chi^{2}=32.13$, $\mathrm{p}<0.001$ ) effect on firm survival. But the negative coefficient is negative meaning that TMT with a higher level of international education is associated with a lower level of survival rate. This result is the opposite of the Hypothesis 2a. Thereby, Hypothesis 1 and Hypothesis 2a are not supported. Model 4 includes the effect of TMT international work experience to the analysis. Hypothesis $2 \mathrm{~b}$ posits that TMT international work experience positively associates with firm survival. The marginally significant $\left(\chi^{2}=45.82, p<0.1\right)$ positive coefficient of the TMT international work experiences suggests that TMT with more years of average international experiences positively influences the firms' survival. Therefore, hypothesis $2 b$ is supported.

I added the last independent variable, the percentage of foreigners in TMT in Model 5. The positive and significant $\left(\chi^{2}=76.59, p<0.05\right)$ coefficient shows TMT percentage of foreigners also positively associates with firm survival. Thus, hypothesis $2 \mathrm{c}$ is supported.

Hypothesis $3 \mathrm{a}, 3 \mathrm{~b}, 3 \mathrm{c}$ and $3 \mathrm{~d}$ suggest that the level of industry globalization negatively moderates the main effects. Model 6 includes the interaction between UNGC participation and IG. Contrary to the Hypothesis 3a, the industry globalization does not have significant moderating effects on relationship between UNGC participation and survival. Model 7, 8 and 9 respectively include interactions between IG and TMT international education, TMT international work experience, and TMT percentage of foreigners. But none of them is significant. Thereby, the result shows no significant moderating effect in the model. 
Model 10 is the full model including the main effects and all moderating effects. The negative and marginally significant coefficients $(\mathrm{p}<0.1)$ of interaction terms (TMT international education and TMT international work experience) shows the marginal negative moderating effect of IG on the main effects. So hypothesis $3 b$ and $3 c$ which suggest that IG weakens the main effects of TMT international education and work experience on firms' survival are partially supported by the full model. Hypothesis $3 \mathrm{~d}$ is not supported.

\section{DISCUSSION AND CONCLUSION}

This essay first proposed the concept of global orientation and then tests its association with ECF subsidiaries' survival. Global orientation is exclusively for ECFs that strive to absorb new knowledge from foreign markets by including TMT that have a high level of international background and by participating in globally reputable organizations or alliances. The result confirms the hypotheses that TMT international work experiences and TMT percentage of foreign executives positively associate with ECFs' survival. I proposed that the relationships are negatively moderated by the level of industry globalization, which is partially supported. The result shows TMT international education is significantly negatively associated with ECFs' survival, which is the opposite of Hypothesis 2a. It is interesting to the further investigate this phenomenon and detect whether TMT international education firm survival is negatively associated with firm survival.

This study has some contributions to the literature of global mindset and of survival. First, sufficient research has studied the global mindset on the individual level, while limited research explored the global mindset on the organizational level. Global 
orientation essentially reflects the global mindset at the organization-level. Global orientation comprises the inside factor TMT international composition, which is the potential of gaining global perspectives, and the outside actions that reflect the firms' realized global-oriented practices. The purpose of global orientation is to obtain diverse perspectives and absorb new knowledge of foreign operations. Second, current research focuses on the impact of the global mindset on firms' financial performance. This study links the global orientation to firm survival in the context of emerging country firms operating in the U.S.

This study also makes some empirical contributions. The findings speak to the importance of TMT foreign composition and average international work experience for ECFs subsidiaries' survival. Consistent with the expectation, I found high level of TMT international work experience and large percent of TMT foreign members positively influences survival. It provides some implications to ECFs' appointment of top management teams. Contrary to the expectation, global-oriented practices are not significantly associated with survival. However, this result should be treated with caution because I included only UNGC participation as a global-oriented practice. UNGC participation does not reflect the whole picture; global-oriented practices should also contain alliances, which provide sufficient opportunity for ECFs to interact with foreign firms and partners and to trigger their absorptive capacity. This is one of the limitations of this paper. Future research can enrich the measure of realized global-oriented practices. Another limitation of the essay is the limited data availability. Besides some listed firms, most of the subsidiaries are private and do not release their TMT information. This inevitably shrinks the sample size and creates biases. Furthermore, because ECFs' board 
of directors (BOD) have different power and mechanism in the relationship with TMT (Wu, 2002), it is meaningful to investigate the influence of BODs' composition on the global orientation and firm survival. 
Figure 2-1 Essay 2 model

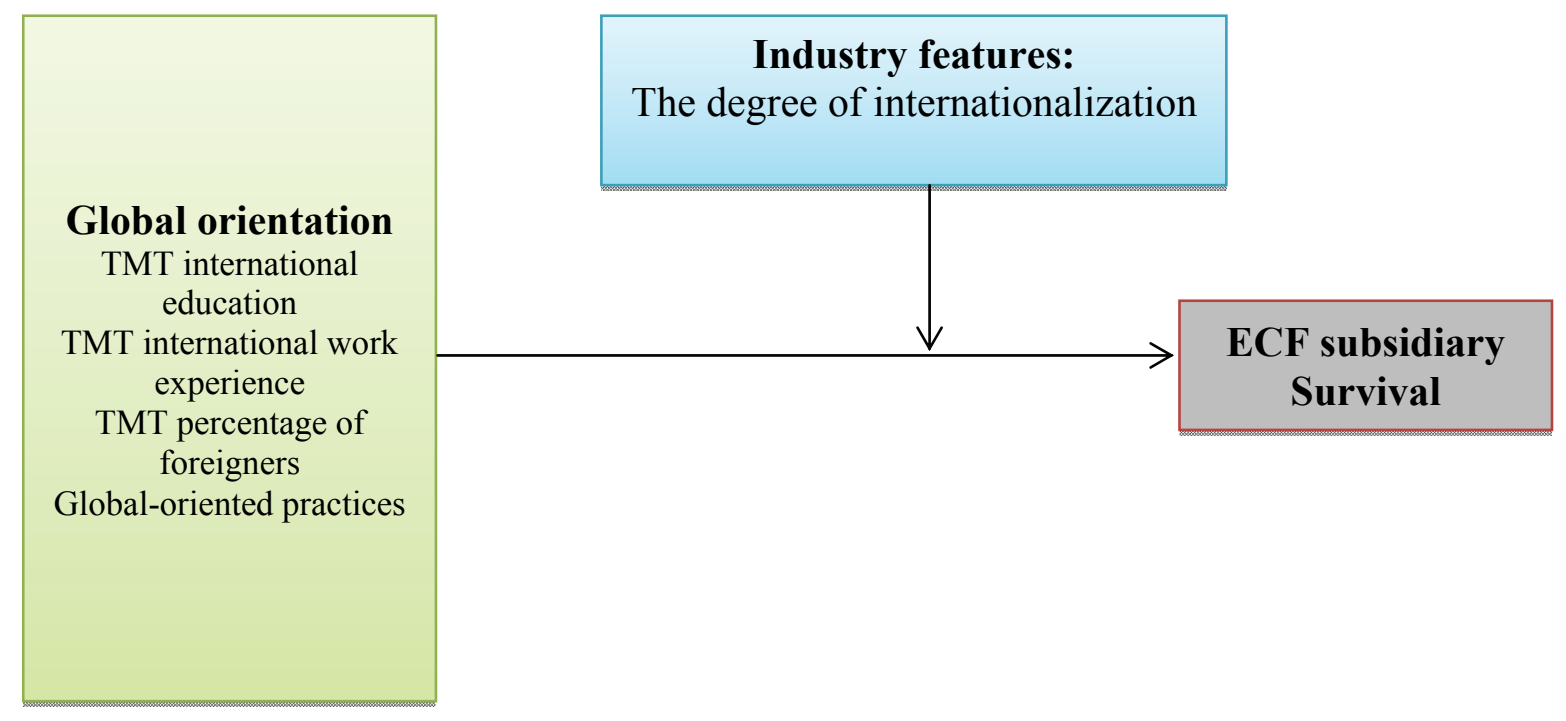


Table 2-1 Descriptive Statistics

\begin{tabular}{|c|c|c|c|c|c|c|c|c|c|c|c|c|c|}
\hline Variable & Mean & Std. Dev. & 1 & 2 & 3 & 4 & 5 & 6 & 7 & 8 & 9 & 10 & 11 \\
\hline 1. Size & 295.28 & 1471.12 & 1.0000 & & & & & & & & & & \\
\hline 2. Org. form & .30 & .46 & 0.2297 & 1.0000 & & & & & & & & & \\
\hline 3. Ownership & .24 & .43 & -0.0849 & -0.3312 & 1.0000 & & & & & & & & \\
\hline 4. Industry & 418.65 & 125.33 & 0.0169 & -0.2415 & 0.1394 & 1.0000 & & & & & & & \\
\hline 5. Parent age & 19.36 & 19.87 & -0.0274 & -0.2431 & 0.5336 & 0.0678 & 1.0000 & & & & & & \\
\hline 6. Parent intl. experience & 8.54 & 20.95 & -0.0493 & -0.2092 & 0.2068 & 0.3635 & 0.2103 & 1.0000 & & & & & \\
\hline 7. UNGC Meb. & .09 & .28 & 0.3142 & -0.0700 & 0.2564 & -0.1144 & 0.1848 & 0.0882 & 1.0000 & & & & \\
\hline 8. TMT Intl Edu. & 2.26 & 1.83 & -0.1374 & -0.1477 & 0.0376 & 0.1128 & 0.1113 & 0.1667 & -0.1470 & 1.0000 & & & \\
\hline $\begin{array}{lll}\begin{array}{l}\text { 9.TMT } \\
\text { experience }\end{array} & \text { Intl. } & \text { worl } \\
\end{array}$ & 7.16 & 7.04 & -0.1246 & -0.2268 & 0.1237 & 0.1711 & 0.2189 & 0.2984 & -0.0498 & 0.4694 & 1.0000 & & \\
\hline 10. \%foreign TMT Meb. & .38 & .40 & -0.0960 & -0.3142 & -0.0738 & 0.1317 & 0.0716 & 0.1946 & -0.0653 & 0.4330 & 0.4045 & 1.0000 & \\
\hline 11.Industry globalization & .60 & .24 & -0.1839 & 0.0694 & 0.1830 & 0.2194 & 0.1624 & 0.0618 & -0.0008 & -0.0660 & 0.0450 & -0.1532 & 1.0000 \\
\hline
\end{tabular}


Table 2-2 Weibull survival analysis on emerging country firms' global orientation

\begin{tabular}{|c|c|c|c|c|c|c|c|c|c|c|}
\hline & $\begin{array}{l}\text { M1 } \\
\text { Baseline }\end{array}$ & $\begin{array}{l}\text { M } 2 \\
(\mathrm{H} 1)\end{array}$ & $\begin{array}{l}\text { M 3 } \\
(\mathrm{H} 2 \mathrm{a})\end{array}$ & $\begin{array}{l}\text { M 4 } \\
(\mathrm{H} 2 \mathrm{~b})\end{array}$ & $\begin{array}{l}\text { M 5 } \\
(\mathrm{H} 2 \mathrm{c})\end{array}$ & $\begin{array}{l}\text { M 6 } \\
(\mathrm{H} 3 \mathrm{a})\end{array}$ & $\begin{array}{l}\text { M7 } \\
(\mathrm{H} 3 \mathrm{~b})\end{array}$ & $\begin{array}{l}\text { M8 } \\
(\mathrm{H} 3 \mathrm{c})\end{array}$ & $\begin{array}{l}\text { M9 } \\
(\mathrm{H} 3 \mathrm{~d})\end{array}$ & $\begin{array}{l}\text { M10 } \\
\text { (Full } \\
\text { Model) }\end{array}$ \\
\hline Size & $\begin{array}{l}.00 \\
(.0011)^{*}\end{array}$ & $\begin{array}{l}.00 \\
(.002)\end{array}$ & $\begin{array}{l}.00 \\
(.001)\end{array}$ & $\begin{array}{l}.00 \\
(.001)\end{array}$ & $\begin{array}{l}-.00 \\
(.000)\end{array}$ & $\begin{array}{l}.00 \\
(.000)\end{array}$ & $\begin{array}{l}-.00 \\
(.001)\end{array}$ & $\begin{array}{l}-.00 \\
(.001)\end{array}$ & $\begin{array}{l}-.00 \\
(.000)\end{array}$ & $\begin{array}{l}-.00 \\
(.000)\end{array}$ \\
\hline Organization form & $\begin{array}{l}-1.06 \\
(.599)^{*}\end{array}$ & $\begin{array}{l}-.90 \\
(.622)\end{array}$ & $\begin{array}{l}-.28 \\
(.676)\end{array}$ & $\begin{array}{l}-.29 \\
(.680)\end{array}$ & $\begin{array}{l}.38 \\
(.704)\end{array}$ & $\begin{array}{l}-.98 \\
(.642)\end{array}$ & $\begin{array}{l}-.36 \\
(.699)\end{array}$ & $\begin{array}{l}-.387 \\
(.693)\end{array}$ & $\begin{array}{l}.44 \\
(.789)\end{array}$ & $\begin{array}{l}.44 \\
(.819)\end{array}$ \\
\hline Ownership & $\begin{array}{l}-1.46 \\
(.629) * *\end{array}$ & $\begin{array}{l}-1.60 \\
(.629) * *\end{array}$ & $\begin{array}{l}-1.54 \\
(.620)^{* *}\end{array}$ & $\begin{array}{l}-1.58 \\
(.611) \dagger\end{array}$ & $\begin{array}{l}-.82 \\
(.638)\end{array}$ & $\begin{array}{l}-1.68 \\
(.650) \dagger\end{array}$ & $\begin{array}{l}-1.63 \\
(.639) \dagger\end{array}$ & $\begin{array}{l}-1.69 \\
(.624) * *\end{array}$ & $\begin{array}{l}-.43 \\
(.715)\end{array}$ & $\begin{array}{l}-.46 \\
(.707) \\
\end{array}$ \\
\hline Industry & $\begin{array}{l}-.00 \\
(.002)\end{array}$ & $\begin{array}{l}-.00 \\
(.002)\end{array}$ & $\begin{array}{l}.00 \\
(.002)\end{array}$ & $\begin{array}{l}.00 \\
(.002)\end{array}$ & $\begin{array}{l}.00 \\
(.002)\end{array}$ & $\begin{array}{l}-.00 \\
(.002)\end{array}$ & $\begin{array}{l}-.00 \\
(.003)\end{array}$ & $\begin{array}{l}-.00 \\
(.003)\end{array}$ & $\begin{array}{l}-.00 \\
(.003)\end{array}$ & $\begin{array}{l}-.00 \\
(.003) \dagger\end{array}$ \\
\hline Parent age & $\begin{array}{l}.015 \\
(.013)\end{array}$ & $\begin{array}{l}.02 \\
(.013)\end{array}$ & $\begin{array}{l}.02 \\
(.014) \\
\end{array}$ & $\begin{array}{l}.016 \\
(.014)\end{array}$ & $\begin{array}{l}.017 \\
(.019)\end{array}$ & $\begin{array}{l}.02 \\
(.013)\end{array}$ & $\begin{array}{l}.02 \\
(.014) \\
\end{array}$ & $\begin{array}{l}.01 \\
(.014)\end{array}$ & $\begin{array}{l}.02 \\
(.023)\end{array}$ & $\begin{array}{l}.02 \\
(.027) \\
\end{array}$ \\
\hline Parent Intl. Experience & $\begin{array}{l}.00 \\
(.015)\end{array}$ & $\begin{array}{l}-.00 \\
(.016)\end{array}$ & $\begin{array}{l}.00 \\
(.019) \\
\end{array}$ & $\begin{array}{l}-.01 \\
(.016)\end{array}$ & $\begin{array}{l}-.032 \\
(.017)\end{array}$ & $\begin{array}{l}-.00 \\
(.016)\end{array}$ & $\begin{array}{l}.01 \\
(.020)\end{array}$ & $\begin{array}{l}-.01 \\
(.016)\end{array}$ & $\begin{array}{l}-.04 \\
(.021)^{*}\end{array}$ & $\begin{array}{l}-.04 \\
(.022)^{*}\end{array}$ \\
\hline UNGC Meb. & & $\begin{array}{l}-17.88 \\
(2341.44)\end{array}$ & $\begin{array}{l}19.26 \\
(1282.25)\end{array}$ & $\begin{array}{l}20.72 \\
(2735)\end{array}$ & $\begin{array}{l}17.07 \\
(1669) \\
\end{array}$ & $\begin{array}{l}18.24 \\
(7491)\end{array}$ & $\begin{array}{l}19.77 \\
(1347)\end{array}$ & $\begin{array}{l}20.65 \\
(1914)\end{array}$ & $\begin{array}{l}23.67 \\
(3136)\end{array}$ & $\begin{array}{c}24.59 \\
(4567)\end{array}$ \\
\hline Avg. Intl. Education & & & $\begin{array}{l}-.400 \\
(.125)^{* * *}\end{array}$ & $\begin{array}{l}-.50 \\
(.139) * * *\end{array}$ & $\begin{array}{l}-.41 \\
(.137)^{* *}\end{array}$ & & $\begin{array}{l}-.247 \\
(.500)\end{array}$ & $\begin{array}{l}-.52 \\
(.146)^{* * *}\end{array}$ & $\begin{array}{l}-.51 \\
(.167)^{* *}\end{array}$ & $\begin{array}{l}-1.50 \\
(.611) \dagger\end{array}$ \\
\hline $\begin{array}{l}\text { Avg. Intl. } \\
\text { Work experience }\end{array}$ & & & & $\begin{array}{l}.06 \\
(.039) \dagger\end{array}$ & $\begin{array}{l}-.05 \\
(.041)\end{array}$ & & $\begin{array}{l}-.05 \\
(.149)\end{array}$ & $\begin{array}{l}-.05 \\
(.149)\end{array}$ & $\begin{array}{l}-.05 \\
(.043)\end{array}$ & $\begin{array}{l}-.035 \\
(.15)^{*}\end{array}$ \\
\hline TMT \% foreigner & & & & & $\begin{array}{l}6.78 \\
(2.537) * *\end{array}$ & & & & $\begin{array}{l}9.45 \\
(4.89) *\end{array}$ & $\begin{array}{l}10.51 \\
(4.15) \dagger\end{array}$ \\
\hline Industry Globalization(IG) & & & & & & $\begin{array}{l}78 \\
(1.198)\end{array}$ & $\begin{array}{l}1.49 \\
(2.192)\end{array}$ & $\begin{array}{l}-.22 \\
(2.122)\end{array}$ & $\begin{array}{l}4.46 \\
(1.689) * *\end{array}$ & $\begin{array}{l}-.21 \\
(2.927)\end{array}$ \\
\hline IG*UNGC Meb. & & & & & & $\begin{array}{l}.31 \\
(17064)\end{array}$ & & & & $\begin{array}{l}-10.17 \\
(6390)\end{array}$ \\
\hline IG*Avg.Intl. Edu & & & & & & & $\begin{array}{l}-.22 \\
(.682)\end{array}$ & & & $\begin{array}{l}1.23 \\
(.825) \dagger\end{array}$ \\
\hline IG*Avg.Intl.Work & & & & & & & & $\begin{array}{l}.16 \\
(.213)\end{array}$ & & $\begin{array}{l}.42 \\
(.234) \dagger\end{array}$ \\
\hline $\mathrm{IG}^{* 0} \%$ Foreigner & & & & & & & & & $\begin{array}{l}-.65 \\
(7.96)\end{array}$ & $\begin{array}{l}-1.47 \\
(8.06)\end{array}$ \\
\hline No. Observation & 115 & 115 & 115 & 115 & 115 & 115 & 115 & 115 & 115 & 115 \\
\hline Log Likelihood & -56.84 & -53.82 & -48.26 & -46.97 & -31.59 & -53.61 & -47.98 & -46.44 & -27.84 & -24.83 \\
\hline
\end{tabular}




\begin{tabular}{|c|c|c|c|c|c|c|c|c|c|c|}
\hline $\operatorname{LR} \chi^{2}(\mathrm{df})$ & $26.08(6)$ & $32.13(7)$ & $43.25(8)$ & $45.82(9)$ & $76.59(10)$ & $32.55(9)$ & $43.80(10)$ & $46.88(11)$ & $84.09(12)$ & $90.11(15)$ \\
\hline$\beta_{0}$ & $-5.97 * * *$ & $-5.78 * * *$ & $-6.63 * * *$ & $-6.57 * * *$ & $-6.49 * * *$ & $-5.70 * * *$ & $-6.04 * *$ & $-7.50 * * *$ & $-5.26 * *$ & $-10.62 * *$ \\
\hline (p value) & 0.0002 & $<0.0001$ & $<0.0001$ & $<0.0001$ & $<0.0001$ & 0.0002 & $<0.0001$ & $<0.0001$ & $<0.0001$ & $<0.0001$ \\
\hline
\end{tabular}

$\dagger \mathbf{p}<0.1, * \mathbf{p}<0.05, * * \mathbf{p}<0.01, * * * \mathbf{p}<0.001$. Survival= 1(firm survives); Survival=0(firm does not survives); 
ESSAY 3. UNGC participation announcements and stock market reactions: signaling and institutional perspectives on the effects of firm-level and country-level attributes

\section{ABSTRACT}

Will affiliation lead to legitimacy? If affiliation is considered a process of signaling legitimacy, what information interrupts or favors the process? In the context of joining the United Nations Global Compact (UNGC), this essay examines the impacts of firms' attributes on the market reaction to the announcement of UNGC participation. I argue that the dynamics between firm-level and country-level attributes and the focal signal impacts the market reaction to the announcement of the event. Information vacancy favors the signaling delivery. Using an event study of a sample of 117 UNGC participation announcements from 2000 to 2012, I found a U-shaped relationship between firms' visibility and the market reactions on UNGC participation announcements. Meanwhile, the market positively reacts to the firms that have yet disclosed their sustainability performance (SP). Results further show that the home country type amplifies and loosens the impact of visibility on market responses to UNGC participation announcements in different contexts.

Key words: UNGC, Stock Performance, Affiliation, Signaling Theory 


\section{INTRODUCTION}

In today's competitive global market, obtaining and maintaining legitimacy are crucial for both emerging country firms (ECFs) and developed country firms (DCFs) because improving external legitimacy increases the chance for survival (DiMaggio \& Powell, 1983). One of the strategies for increasing legitimacy is to affiliate legitimate international organizations or reputed firms. Some studies have investigated market reactions to joint venture announcements (Madhavan \& Prescott, 1995), and others have addressed the context of the Initial Public Offering (IPO) (e.g. Titman \& Trueman, 1986) and firms' joining UNGC (Janney, Dess, \& Forlani, 2009). Most of the research draws attention to the contingent factors of events, and investigates their influences on the stock performance. Limited research has examined how the specific heterogeneity of firms affects the market returns (Gaur, Malhotra, \& Zhu, 2013). Recent work on market reaction to UNGC participation (Janney et al. 2009) compares the influences of country difference on the market returns. But merely home country differences (Europe vs. U.S.) with two controls (firm age and firm size) are hardly able to present the whole picture. Applying the signaling theory and the institutional theory, this paper investigates the impacts of firms' inherent attributes and their interactions on the market reaction to UNGC participation. I propose that firm-level and country-level attributes impact the effectiveness of the signaling process. Signals with information vacancy are inclined to experience strong and effective signal delivery.

This paper contributes to the literature and the practice in three ways. It contributes to signaling theory by probing the impact of the dynamics between inherent attributes and the focal signal, and by revealing the influence of information vacancy on 
the signaling process in pooling equilibrium. Furthermore, it enriches the research on the market reaction to UNGC participation by introducing multiple-level attributes to the model from a more holistic perspective. Lastly, it provides practical implications to both ECFs and DCFs on the strategy of affiliation. The findings indicate that the outcome of affiliation events relies on firms' visibility, and whether they have released related information before the event. These relationships are contingent on their home country type, namely, emerging country or developed country.

\section{LITERATURE REVIEW}

\section{Signaling theory}

Signaling theory was mainly applied in evolutionary biology. The body of work examines the communication between individuals. Akerlof (1970) and Spence (1973) introduced signaling theory into the field of economics. Spence used the job market as a context to describe signal sending and receiving in the hiring process. He suggested that signals are critical sources of information when limited objective information is available. He proposed that education functions as a signal of job hunters' future productivity, and potential employers evaluate job hunters by the signal they receive. People with low productivity (ability) tend to acquire the lower level of education because the higher level of education is costly, difficult, and time-consuming (Spence, 1973). In this way, the signal of education serves as an honest signal in the separating equilibrium. Therefore, signals differentiate individuals with different attributes, and attenuate the likelihood of adverse selection and moral hazard (Folta \& Janney, 2004; Janney \& Folta, 2006). This theory has been widely used in the fields of management, psychology, anthropology, and biology. The field of management has grown this signaling theory into broader areas of 
research, such as recruiting literature (e.g. Chapman, Uggerslev, Carrol, Piasentin, \& Jones, 2005; Ehrhart \& Ziegert, 2005), crisis situation (Marcus \& Goodman, 1991), and consumer behavior. Some researchers have extended the theory to the firm level, such as Milgrom \& Roberts (1986), Ross (1977), Janney et al., (2009), and so on. They generally asserted that firms signal to a market to indicate firms' quality, commitments, or performance (e.g., Certo, 2003).

One of the crucial conditions that make signals serve as a source of effective information is the separating equilibrium (Janney \& Folta, 2006; Spence, 1974) whereby different types signal senders choose different corresponding messages and the signal receivers are able to differentiate the unobservable attributes of the signal senders. This separating equilibrium will be interrupted when feedback disagrees with the perceived correlation between the signal and certain unobservable attributes (Spence, 1974). If signals are not able to differentiate firms' attributes, the market has reached a pooling equilibrium where signals are ineffective sources of information (Spence, 2002).

In the real world, pooling equilibrium is more common and researchers have found that stockholders are faced with mixed signals in concurrence (Certo, Daily, Cannella, \& Dalton, 2001; Florin, Lubatkin, \& Schulze, 2003). According to Spence (2002), the more information available, the more accurate the receivers' evaluation of the senders' signals. By comparing the consistent and inconsistent information, the signal receivers have more ability to interpret the signals accurately (Heil \& Roberton, 1991).

However, I argue that multiple signals, or signals with mixed information, do not necessarily raise the accuracy of stockholders' interpretation on firms' attributes. Signals may not function effectively under the interruption of other information about the firm. 
The interruptive information could be divided into two types. One is the news or events that occur simultaneously with the focal event, all of which indicate the unobservable attributes of the firm (Spence, 2002); the other type is observable attributes of firms, or past events, or already-obtained evaluations or images of firms. Signals implicate unobservable attributes of firms. Both unobservable and observable attributes simultaneously influence the market's evaluation of the firms' unobservable attributes. When the complex information exists in conjunction, the effectiveness of signals' function is contingent on the level of consistency among the multiple signals. The first type of interruptive information is easy to identify and weed out empirically, but the second type of information is difficult to waive. This paper is focusing on the impact of the second type of information on the market reactions of firms' joining UNGC.

I further argue that the market reaction will be simply active if the signal conveys brand new information that has rarely been sent out. If the signals are not brand new, but are consistent with other signals or information, the focal signal serves as confirmation or support for the original or existing evaluation of firms' attributes. If the focal signal is the opposite of the existing information, the market will be confused because the focal signal conveys different messages to the market (Figure 3-1). Based on this rationale, this paper investigates the impacts of the firm-level and country-level attributes on market reactions to firms' affiliation announcements (UNGC participation). I further propose that signals that confirm the previous signals or information about the firm will bring less active market reaction, while clear-cut new signals with information vacancy will lead to active and strong market reaction. Moreover, signals inconsistent with previous observable 
information give rise to complex market reactions, depending on the degree of consistency of information.

\section{Institutional theory}

Legitimacy and isomorphism are two of the key concepts in neo-institutional theory. To obtain the legitimacy, organizations endeavor to imitate the legitimate organizations' behaviors in the market (DiMaggio \& Powell, 1983). Emerging market firms listed in the U.S. stock markets face the pressure of competition and strive to gain legitimacy for survival. Their competitors mostly come from developed countries where firms possess advanced organizational practices. To be specific, perceptions about ECFs in developed countries are normally not very positive in terms of firm information transparency and sustainable development. ECFs tend to be hesitant to disclose voluntary information mainly resulting from the imprinting effect of their home countries' environment, where there is lack of restrictions on disclosing both good and bad news. For example, a large Chinese telecommunication company, Huawei, was accused of a lack of transparency and was threatened with banishment from doing business in the U.S. by the House Permanent Select Committee on Intelligence in 2012 (Hille, 2013). Thus, revealing both firms' bad and good news is a big stride for ECFs who want to gain legitimacy in the foreign market, title themselves as a multinational with great transparency and sustainability activities, and stand out in the global market. Under the pressure, Huawei, has pledged to disclose more detailed financial information for shareholders in early 2013, in the hope of clearing the obstruction on its way of global expansion (Hille, 2013). 
It is normally considered that one of ECFs' observable attributes is less transparency and less sustainability. Thus, the attributes endow ECFs with less legitimacy in the foreign market. According to the institutional theory, ECFs tend to choose isomorphic activities to show their willingness and ability to provide transparency about its sustainability activities and performance, compared with its competitors (Janney et al., 2009). Affiliations and enforcements that employ a third party to validate the quality of ECFs may be an effective way of indicating ECFs' certain commitments and legitimacy. By affiliating to prestigious organizations or alliances, ECFs may acquire reputation and legitimacy of other firms in the organization or alliance (Baum \& Oliver, 1992). For ECFs, whose pre-assumed attributes are less transparent and less sustainable, such affiliation is especially valuable. Joining a well-known worldwide organization, such as UNGC, ECFs indicate the commitment to transparency and sustainability, and gains for them greater legitimacy and competence, compared with their peers.

\section{HYPOTHESES}

Markets have an informational gap (Spence, 1973). This gap is especially apparent to ECFs' stakeholders mainly because ECFs are relatively new and thus invite speculations in the global market. Given limited information, stakeholders such as investors and potential exchange partners, heavily rely on signals that convey ECFs' behaviors and events (Spence, 1973), through which they infer ECFs' attributes and predict their future performance. According to Stuart, Hoang, \& Hybels (1999), effective signaling behaviors improve the firms' chances for survival. Affiliation with globally legitimized organization may signal firms' certain commitments and legitimacy, and implicate that they may likely survive the short term into the future (Meyer \& Rowan, 
1977; Stuart et al., 1999). Such activities are visible, observable actions that link the quality of two or more exchange partners, in transactions such as investors (Janney \& Folta, 2006), alliance (Stuart et al., 1999), and joining UNGC (Janney et al., 2009). This is in line with Cetindamar \& Husoy (2007) who suggested that one of the economic reasons for becoming UNGC members is to compete in the global market. In addition, UNGC's bi-annual survey (Communication on Progress or COP) on each participant and their disclosure on their performances in annual reports (for publicly held companies) enhance stakeholders' confidence in the accuracy of information (Feddersen \& Gilligan, 2001). Therefore, joining UNGC will signal both ECFs' willingness and ability to behave ethically by applying higher international standards such as transparency and sustainability, compared to their competitors. Therefore, it may reinforce stakeholders' confidence in firms' future growth.

However, as proposed above, signals of obtaining legitimacy may be confounded with other related inherent attributes or postnatal characteristics/ information about the firm. The inconsistency of the information may cause confusion and interruption. In the context of joining UNGC, the interruptive information related to transparency and sustainability includes the easiness of acquiring firms' information, the availability of obtaining their sustainability performance (SP), and other related observable attributes such as home country type. The essay is focused on the impact of the interruptive information on the market reaction to firms' joining UNGC. 


\section{Visibility}

Visibility is a critical attribute of organizations. It helps attenuate the asymmetric information between a firm's management and its stakeholders (Brammer \& Millington, 2006). The market tends to have limited information about the firms with little visibility. Reflecting the dynamic between signals and the market reaction (Figure 3-1), the most effective signaling occurs when the firm's signal is brand new to the market. Because there is no interruptive information that hampers the signal delivery, the new signal can bring effective market reaction. In the case of firms with little visibility, the market is inclined to react effectively to the announcements of UNGC participation and have positive expectations for less visible firms which send the clear-cut signal of sustainability without interruption. Moreover, firms with little visibility are less likely to receive a higher level of scrutiny (Brammer \& Milington, 2006). The cost of the affiliation is smaller for them than those firms with greater visibility. Thus, the market tends to show their confidence in less visible firms' affiliation to UNGC.

In the case of firms with visibility, the market tends to possess more information about firms, leading to a greater possibility for the market to attain interruptive information about firms' sustainability. Whether the interruptive information conforms or fails to confirm to the focal signal of sustainability, the market reaction tends to be less effective or highly complex (refer to Figure 3-1). So in this case, the focal signal is more likely to serve as the function of confirming or confounding with the previous information. Consequently, the market reaction to visible firms' announcements tends to be weaker. 
Moreover, the greater visibility makes it easier for stakeholders to acquire information about the firms' actions and evaluate their performance. Their actions and sustainability performance will be closely securitized and timely reported. Stakeholders are likely to take a greater interest in organizations, at least in organizations of which they are aware of (Meznar \& Nigh 1995). Once the signal has been sent out to the public, these visible firms will face excessive pressure and close inspection on how well they realize the commitment. In the meantime, the media plays an important role by leading public attention to certain issues and organizations. Institutional theory argues that organizations choose from a spectrum of responses to external pressure from stakeholders, ranging from avoidance to compliance (Oliver, 1991). Firms with visibility tend to choose compliance due to close scrutiny from the public and "constituency pressure" (Erfle \& McMillan, 1990). Empirical studies found that firms with greater visibility tend to make larger philanthropic gifts and are more inclined to be motivated in doing so (Saiia, 2000). Thus, the more visibility the firm has, the more possibility that it will follow the rules, thereby gaining legitimacy.

Under this circumstance, firms with the greatest visibility bear more burdens after affiliation. They ought to disclose their sustainability performance honestly and timely, and their performance is always expected to be positive. Any minor slight glitch may be amplified to the public, which leads to higher frequency of crisis management, and increased resources and costs to cover the negative influence. This is one of the reasons that visible organizations yield lower profit margins than less visible firms, an empirical finding in the petroleum industry by Erfle \& McMillan (1990). When visible firms face scrutiny and stakeholders' pressure from the external environment (Miles, 1987), 
investors tend to be cautious of these firms' participation in UNGC, because the potential for rising costs tends to outweigh the benefit. The market is inclined to have conservative prediction or negative reaction to visible firms' affiliation to UNGC.

However, this may not hold for firms with the greatest visibility. Firms with the greatest visibility are mostly the leading firms in the global market. As UNGC's principle indicates, participating in UNGC does not essentially raise the bar in the area of human rights, labor standards, the environment, and anti-corruption. Many leading firms have already reached or exceed the bar in sustainability practices. The purpose is to have participants promote these principles by publicly disclosing their practice and promoting their commitment to the principles. This is particularly the case of leading companies, who have legitimacy and apply advanced organizational practices to maintain the legitimacy. Thus, the most visible firms with advanced sustainability practices join the UNGC with controllable cost and act as a leader in the practice of sustainability.

The most visible firms have legitimacy and advanced practices. Young affiliation organizations, such as UNGC in early 2000s, had less legitimacy. In order to raise the legitimacy of newly established UNGC, U.N. Secretary General Kofi Annan invited giant firms from Europe, Asia, and America in the early years of UNGC's establishment. I call this phenomenon inverted affiliation. Contrary to the traditional theory that firms affiliate to organizations for the purpose of obtaining legitimacy, in this case a young organization was inviting leading firms to join for the purpose of increasing the organization's own legitimacy and influence in the field or in the world. Therefore, I argue that the acquisition of legitimacy by affiliation is in two ways essential. This phenomenon is especially apparent for new affiliated organizations, such as UNGC. In the context of 
inverted affiliation, the cost of participation tend to be low to the most visible firms which do not need to raise the bar in sustainability practices and act as leaders in the field. In the extreme situation that the leading firm has met huge criticism of its sustainability practices, it tends to have more resources and capability than other firms to cover the costs.

Market reactions to firms' signals show investors' confidence about the influence of the affiliation on firms' future performance. A positive market reaction indicates investors' confidence in the firms' ability to redeem the promise and meet UNGC requirements. More importantly, it indicates investors' confidence in the fact that the benefits to the firm for joining UNGC outweigh the cost. A negative reaction suggests that investors perceive that the potential costs of UNGC participation outweigh the benefits, and that the firm has shown incompetence in implementing the UNGC rules. As discussed above, firms with limited visibility tend to receive positive market reaction. Firms with visibility tend to receive magnified scrutiny and external pressure, causing more costs than benefits from affiliation. The market reaction is inclined to be negative. Firms with great visibility, most of which are leading firms in the field, tend to have low cost or have more capability to cover the cost of affiliation. Thereby, firms with great visibility are inclined to receive positive market returns on their UNGC participation. Therefore, I propose that,

Hypothesis 1: There is a U-shaped relationship between visibility and stock market reaction (abnormal cumulative return) to UNGC participation announcements. 


\section{The availability of sustainability performance information}

UNGC is an organization created by the United Nations in 1999 for the purpose of improving responsible corporate citizenship. The set of core values of UNGC are in the area of human rights, labor standards, the environment, and anti-corruption. There are ten principles revolving around four core values. Many firms have already fulfilled the principles. So the essence of UNGC is not necessarily to raise the bar on firms' behaviors in these four areas, but to encourage firms to publicly spell out and advocate their commitment to the principles. Thus, some UNGC participants have already been devoted to sustainability practices and provided transparent information about their SP, while some may not have done so.

The information that reflects firms' sustainability performance is Environmental, Social, and Governance scores aggregated by Bloomberg. This score is compatible with the UNGC principles. However, SP scores' availability is contingent on firms' willingness to disclose their information to the public. "The ESG (environmental, social, and governance) data has grown at $11-12 \%$ annually for from 2006-2010. And there is still a long way to go before the company's management and employees understand how their sustainability activities are tied to the company's balance sheet and bottom line" (Bloomberg, 2010).

Firms who have disclosed their SP are those who proactively set themselves apart from their peers. They have proactively started isomorphic behaviors (DiMaggio \& Powell, 1983) to gain legitimacy, and they have already sent out the signals that they endeavor to follow transparency and sustainable development. If these firms announce joining UNGC later on, the signal serves as a confirmation or support to the previous 
information/ the current attribute of the firm, but not as a new signal. On the other hand, for firms that have yet disclosed their ESG scores, the announcement of joining UNGC functions as a brand new signal that indicates the firms' new commitment to sustainability. Under this circumstance, the announcement works as signaling a new attribute of the firm. Thereby, the positive market reaction tends to associate with the firms without ESG disclosure. Therefore, I argue that,

Hypothesis 2: Firms that do not disclose their SPs are more likely to receive positive market reaction to the announcement of joining UNGC than their counterparts.

\section{Moderating effects of the home country type}

Besides transparency and sustainability information, it is likely that investors have more knowledge about country-level inherent attributes of the firms that announced the participation in UNGC. The basic information is the home country type. Foreign markets are more likely to have asymmetric information about the firms from ECFs than about DCFs. The country-level attribute of the firm (i.e. home country type), tends not to be closely attached to a particular firm than its firm-level attributes (e.g. financial performance), but it interrupts with the focal signal the firm tries to send. It is because the foreign market has limited knowledge about ECFs; their evaluation about ECFs more heavily rely on the firm's own behavior and signals they sent out. Reflecting the dynamic between signals and market reaction (refer to Figure 3-1), ECFs' signals tend to function signaling instead of confirming or confounding, and they experience less interruption in the process of signaling, ensuring the effectiveness of the signaling function. When an ECF announces its participation in UNGC, investors incline towards receiving positive 
message from the ECF about its new commitment to sustainability principles. Consequently, the market is inclined to respond positively to the announcement of joining UNGC. Furthermore, the general visibility to the U.S. market of ECFs tends to weaker than the visibility of DCFs. market. Thus, the interaction between visibility and home emerging country will yield more positive market reaction. That is, the U-shaped relationship between the visibility and market reaction to the UNGC participation announcement tend to be loosened for ECFs. The same moderating effect exists for the relationship between ECFs' SP disclosure and market reaction to the UNGC participation announcement.

On the other hand, the U.S. market grasps more information about developed country firms, including positive and negative information about DCFs' performance. There will be more interruption in the process of DCFs' signaling UNGC participation. Merely the signal of joining UNGC is not able to convince the investors about their commitments to sustainability. Other factors, such as visibility and SP disclosure, play bigger roles in the signaling process in the DCFs' case. Therefore, I propose that,

Hypothesis 3a: Home country type moderates the U-shaped relationship between visibility and market reaction to UNGC participation announcements. That is, for DCF, the U-shaped relationship is magnified, while the U-shaped relationship is loosened for ECFs.

Hypothesis 3b: Home country type moderates the relationship between SP disclosure and market reaction to UNGC participation announcements. That is, the relationship is weaker for DCFs, while the relationship is stronger for ECFs. 


\section{DATA AND SAMPLE}

The sample is obtained by matching UNGC participants and firms listed on three major US stock markets, namely, the New York Stock Exchange (NYSE), NASDAQ, and the American Stock Exchange (AMEX). UNGC participants in over-the-counter (OTC) markets are not included. UNGC participants that have been delisted from US stock markets are not included, due to the limited availability of information. The sample has 117 qualified firms, which are from the United States, Britain, Canada, China, Denmark, France, Mexico, India, Germany, Israel, Turkey, Spain, Argentina, Brazil, South Korea, Ireland, Singapore, South Africa, and Switzerland. According to International Monetary Foundation (IMF)'s category, BRICS countries and other 4 countries and regions (Argentina, Hong Kong, Mexico, South Korea, Israel, Turkey) are emerging markets, 12 others are developed countries.

The UNGC participants' list is attained from the UNGC website, and the US stocks' information is obtained mainly from Bloomberg. Other information such as the announcement dates of firms' joining UNGC is manually taken from LexisNexis, the UNGC bulletin, and firms' websites. Stock market returns are acquired from the Center for Research in Securities Pricing (CRSP). All independent and control variables are lagged one year.

\section{Dependent variable}

Stock market reaction to joining UNGC. I use the commonly used method for assessing the signal content of newsworthy events, namely, short-window event study (e.g., Brown \& Warner, 1985; MacKinlay, 1997; McWilliams \& Siegel, 1997), which is 
used to measure "market expectation about firm performance" (Zollo \& Meier, 2007). A positive market reaction suggests the decision is well received by investors; a negative reaction suggests that investors perceive that the potential costs outweigh the benefits. The measure of market reaction is the cumulative abnormal return (CAR) in a short time window. It is calculated by subtracting the predicted abnormal return from the actual abnormal return on each day in the time window. The final CAR is the aggregation of the abnormal returns in the time window. The advantage of using CAR is that it allows the firms' stock price to fully absorb the information before and after the announcement, given the information "leakage" and "absorption" in the time window (Janney et. al, 2009). I include two days before and one day after the announcement in the time window $(-2,1)$, allowing for the information leakage while limiting the confounding effect of other events close to the announcement. The information on firms' stock market return is taken from CRSP (Koh \& Venkatraman, 1991). The calculation of CAR is completed by EVENTUS. I used the CRSP equal weighted index to estimate the market abnormal return.

\section{Independent variables}

Visibility. Empirical evidence typically uses total asset as a measure of its visibility (i.e. Damanpour, 1987). I first transformed the total asset to get the normal distribution by taking the logarithm of total assets. Moreover, visibility is also in the interaction terms of the regression, so I centered the log (total asset) to standardize the variable and lessen the correlation between the visibility and the moderator of home country type. 
Sustainability performance disclosure. ESG score is an annual integrative index of firms' environmental, social and governance performance conducted by Bloomberg. The data availability depends on the willingness of the corporation to disclose the ESG information to the public. In this paper, SP disclosure is a dummy variable. I coded firms that have ESG scores one year prior to the announcement as 0 ; otherwise 1.

\section{Moderator}

Home country type. This moderator is to differentiate whether the firm's home country is an emerging country or a developed country. The category is based on the IMF. The developed country is coded as 0 , and the emerging country is coded as 1 .

\section{Controls}

I employ four control variables in the analysis to weed out the influence of other factors, most of which have been studied in past research. One is the firm age. Young firms suffer "liability of newness" (Stinchcombe, 1965), and have less legitimacy (DiMaggio \& Powell, 1983). Under the circumstance of an event study, young firms tend to receive different market reaction than older firms (Janney et al, 2009). I measure the age of firms by subtracting the year of Initial Public Offering (IPO) from the year of the event. Besides age, size also has power to explain the relative sizes of abnormal returns. In event studies, market reactions for larger firms are smaller, relative to smaller firms (Fama, 1991). Some past research studies sustainability activities in the context of certain single industry. In this way, I controlled for industry (ex. Holmes, 2008; Patten, 1992; Rao, 1994). Janney et al. (2009) pointed out that studies should investigate industry and country effects in the study of market reaction to joining UNGC. Taking both industry 
and country effects into account not only enhances the fine-grained explanation of research findings but also minimizes the confounding problems for research that involves a heterogeneous sample of firms. This paper controls for the industry by taking the first 2 digits of Standard Industrial Classification SIC codes. Country level control is GDP growth. Firms from countries that have higher economic growth signal that firms come from countries that are active in the global market and have potential growth. So these firms' home countries are more likely to welcome globally trendy activities and the firms have more vitality to afford the cost of affiliation. Firm financial performance is measured as the return of assets in the year prior to the UNGC participation announcement. Firms with poor financial performance would have less ability to afford the cost of conducting sustainability activities, thus receive lower market expectations on its joining UNGC.

\section{RESULTS}

Table 3-1 reports the means, standard deviations, and correlations between the variables in the analysis. Inspecting the descriptive statistics, the variables have low correlations ranging from 0.007 to 0.541 , all of which are below 0.70 (see Tabachnick \& Fidell, 2007). The mean variance inflation factor (VIF) is 1.26 , the highest VIF is 1.67 , far below the commonly used cut-point of 10 (Hair, Anderson, Tatham, \& Black, 1998). This shows that there is no multicollinearity problem in the analysis. As Table 3-1 represents, firms' Cumulative Abnormal Return (CAR) has positive correlations with their visibility, SP disclosure (disclosed coded as 0 ; no disclosure coded as 1), which is consistent with the hypotheses. 
I used the event study approach to test the stock market returns for the firms that announced the participation in UNGC. Then, OLS regression is applied to test the models. Table 3-2 presents the results of the regression analyses. The baseline model shows the effect of the control variables. I first tested Hypothesis 1, which suggested that firm visibility has a U-shaped relationship with stock market reaction to UNGC participation announcements. The significant and positive coefficient of squared visibility $(\mathrm{p}<0.01)$ and significant negative coefficient of visibility $(\mathrm{p}<0.01)$ support hypothesis 1 (Figure 3$3)$.

To test hypothesis 2, I add the effect of SP disclosure in Model 2. Model 2 shows the SP disclosure $(\mathrm{Yes}=1 ; \mathrm{No}=0)$ has a significant $(\mathrm{p}<0.05)$ effect on CAR. The coefficient is negative, meaning that the firms that do not have sustainability performance disclosure are more likely to receive positive stock market reaction. The positive marginally significant result supports Hypothesis 2 .

Model 3 includes the interaction between home country type $(\mathrm{ECF}=1$ or $\mathrm{DCF}=0)$ and visibility to examine Hypothesis 3a. Hypothesis 3 a posits that the home country type amplifies the U-shaped relationship between visibility and market reactions. The marginally significant $(p<0.1)$ and negative coefficient of the interaction term between home country type and squared visibility suggests that the impact of visibility on market reaction to UNGC participation announcements becomes stronger for developed country firms, while the U-shaped relationship turns weaker for emerging country firms. In other words, the U-shaped relationship is magnified in the case of DCFs; while this U-shaped relationship is lessened under the circumstance of the ECFs participating in UNGC (Figure 3-4). Thus, hypothesis 3a is partially supported. 
Model 4 shows the moderating effect of home country type on information disclosure about SP. Hypothesis $3 \mathrm{~b}$ suggests that home country type moderates the relationship between SP disclosure and market reaction to the UNGC participation announcement. The result shows no significant interaction terms in the model.

Model 5 is the full model including the main effect and all moderating effects. The significant positive coefficient $(\mathrm{p}<0.001)$ of squared visibility and the negative coefficient $(\mathrm{p}<0.01)$ of visibility reconfirm the result of model 1 and Hypothesis 1 . The significant $(p<0.01)$ effect of SP disclosure on the market reaction (Hypothesis 2$)$ is also shown in the full model. The marginally significant $(\mathrm{p}<0.1)$ interaction term between SP disclosure and squared visibility supports the hypothesis 3a. Besides the U-shaped relationship between visibility and the market reaction, the full model also supports the moderating effects of home country type on the relationship between SP disclosure and the market reaction $(\mathrm{p}<0.1)$. Therefore, the full model supports the hypothesis 1,2 , and $3 b$, and partially supports hypothesis $3 \mathrm{a}$.

\section{DISCUSSION AND CONCLUSION}

The announcement of joining UNGC signals commitments about sustainability, transparency and legitimacy. Besides the contingent characteristics of the event, I propose that the multiple-level information and inherent attributes of the firm impact the market reaction to the announcement of an event. In this essay, I argue that the positive market reaction tends to become stronger when there is little or extremely sufficient previous information about the firm before the UNGC participation announcement. I hypothesize that the firm-level inherent attribute, visibility, has a U-shaped relationship with market reaction to the UNGC participation announcement. Meanwhile, the previous 
information about firms (SP disclosure) negatively associates with market reactions to UNGC participation announcements. The country-level attribute (home country type) moderates these relationships. The findings provide support for the majority of the hypotheses. The empirical results support the U-shaped relationship between visibility and the stock market reaction to joining UNGC announcements. It is also supported that firms without SP disclosures are more likely to receive positive market reactions, while firms that have released their SP tend to experience negative market reactions.

As proposed, the results show that the country-level attribute, home country type, intensifies the U-shaped relationship between DCFs' visibility and their UNGC participation announcements, while it loosens the U-shaped relationship between ECFs' visibility and their UNGC participation announcements. The result shows that (Figure 3-4) the CAR is positive for ECFs' announcements and is negative to DCFs' announcements. Thus, firms from emerging markets benefit more from their UNGC participation announcements than DCFs.

The paper contributes to the literature on signaling theory. Spence (2002) pointed out the pooling equilibrium, where signals are not able to differentiate firms but conflict and confound the unobservable attributes of firms. Under these circumstances, Investors evaluate multiple signals that are inefficient sources of information. Lee (2001) brought forward that that more information will bring more accuracy of stakeholders' evaluation on firms' unobservable attributes. This empirical paper shows that more information does not necessarily increase the accuracy. It depends on the dynamics between the focal signal and previous information about the firm. This paper contributes to the theory by addressing the positive impact of the information vacancy on the effectiveness of the 
focal signal's delivery. Consequently, the paper proposes and tests the direct influence of the firm-level attributes, visibility and SP disclosure, and the moderating effect of the country-level factor, home country type, on the market reaction to the focal signal.

The research also enriches the literature related to affiliation. It points out the notion of inverted affiliation. Opposite to traditional firm affiliation, the affiliated organizations (e.g. UNGC) gain legitimacy by proactively inviting firms with the greatest visibility to join the affiliation. Based on this logic, the paper empirically found a Ushaped relationship between visibility and the market reaction to affiliation announcement. In the study of comparison on the market reactions between firms from Europe and the U.S. (Janney et al., 2009), the explanatory factor is limited to the country difference (European and American), and the controls include only firm size and age, which does not describe the whole picture (Janney et al., 2009). More firm level, country-level and industry-level explanatory variables should be explored (Janney et al., 2009). This paper contributes to this area by examining the market reactions on multiple levels. It captures the firm-level attributes' direct influence and country level's moderating effect on the market reaction to joining UNGC. The findings mainly support the hypotheses. Moreover, this paper integrates the signaling theory with institutional theory to explain the phenomenon.

The findings also contribute to the practice related to ECFs' internationalization. ECFs' affiliation activities are perceived to bring or enhance their legitimacy in the global markets. Compared to DCFs, ECFs have the advantage of information vacancy that favors the effective and positive signaling function. Moreover, holding related information (such as SP in the case of joining the UNGC) before the announcement tends 
to receive a stronger positive market reaction to the brand new signal. For both DCFs and ECFs, limited visibility and extremely great visibility tend to contribute to better market reactions to UNGC participation announcements. In sum, ECFs are more likely to receive positive market reaction and boost investors' confidence in their performance and future development by affiliating UNGC. Thus, affiliation tends to be a favor for ECFs which strives to obtain legitimacy in foreign markets. DCFs incline to benefit less from affiliating UNGC because of the interruption of their previous information in the signaling process.

This paper has some limitations. First, the market reaction in the empirical analysis is limited to the US stock markets. Future research should test the market reaction in the firms' home countries and obtain a holistic view of the market reactions to the announcements of joining UNGC. Second, the event study methodology is limited in that it captures relatively short-term sentiments of the market (Gaur et al., 2013). Third, the measure of visibility in the paper is total assets. There are different measures of visibility in the current literature, such as incidence of news media stories involving companies (Brammer \& Millington, 2006; Meznar \& Nigh, 1995). This alternative measure of visibility could be used for a robust check. Fourth, the paper examines only the market reaction of firms' joining UNGC. Many of the participants became inactive and some were reported excluded from UNGC after years of participation. Future research should conduct longitudinal study on UNGC participants' performance and the sequential events, including being excluded, appraised and rejoined etc., to attain a complete understanding of the signaling costs compared to the benefits from affiliation. 
Figure 3-1 Communication between signal and market

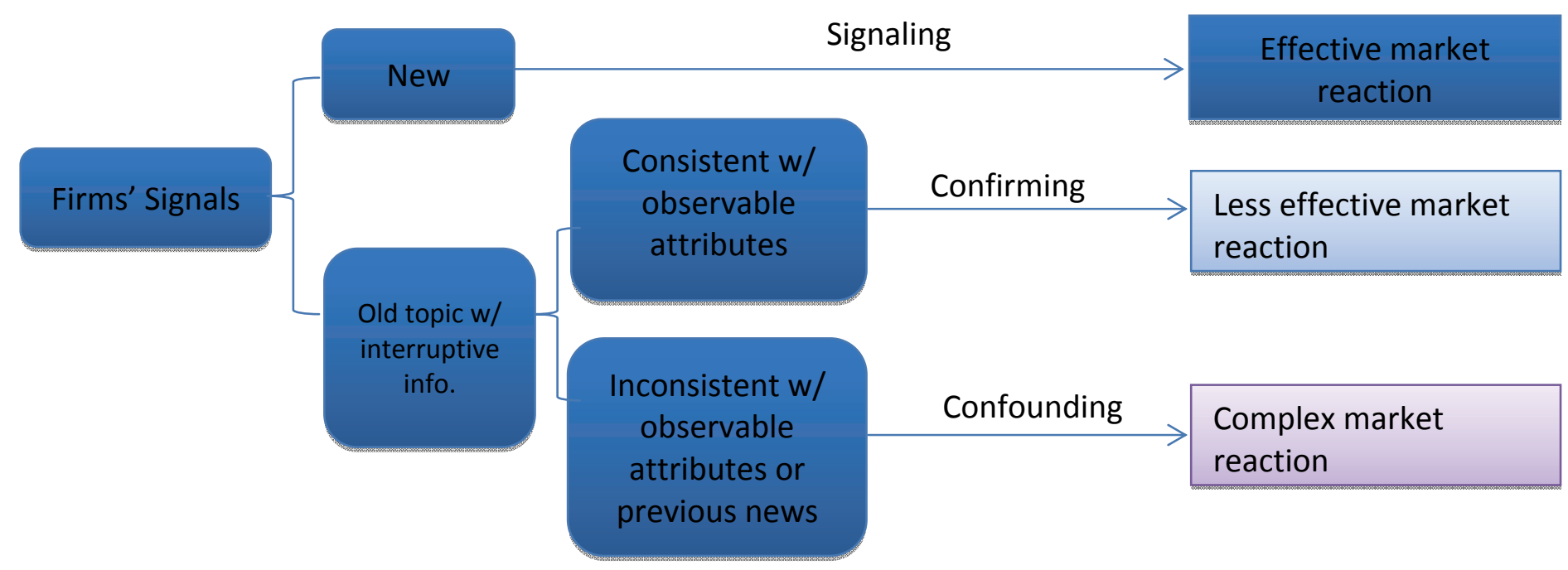

Figure 3-2 Essay 3 model

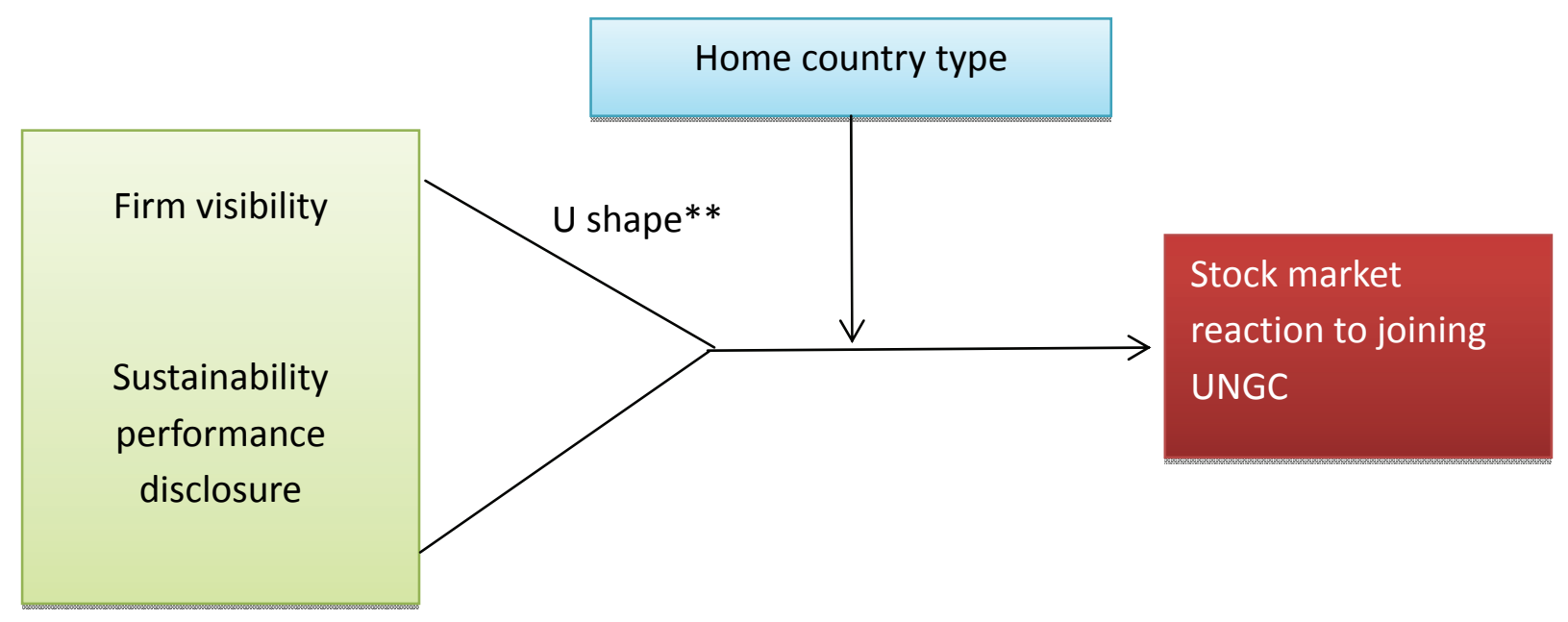


Figure 3-3 Impact of firm visibility on market reaction to UNGC participation announcements

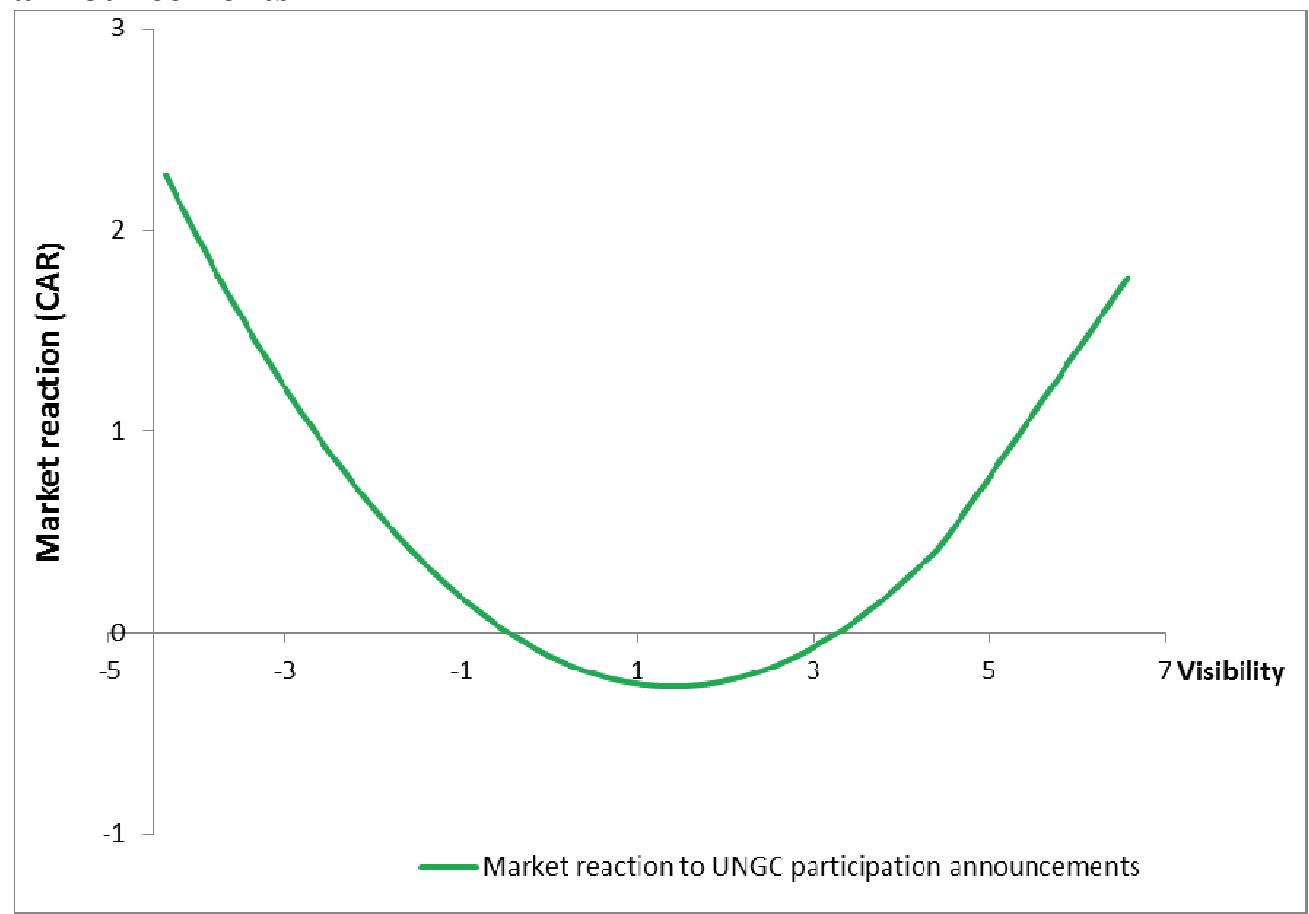

Figure 3-4 Impact of visibility on market reaction to UNGC participation announcements for firms from two types of home country

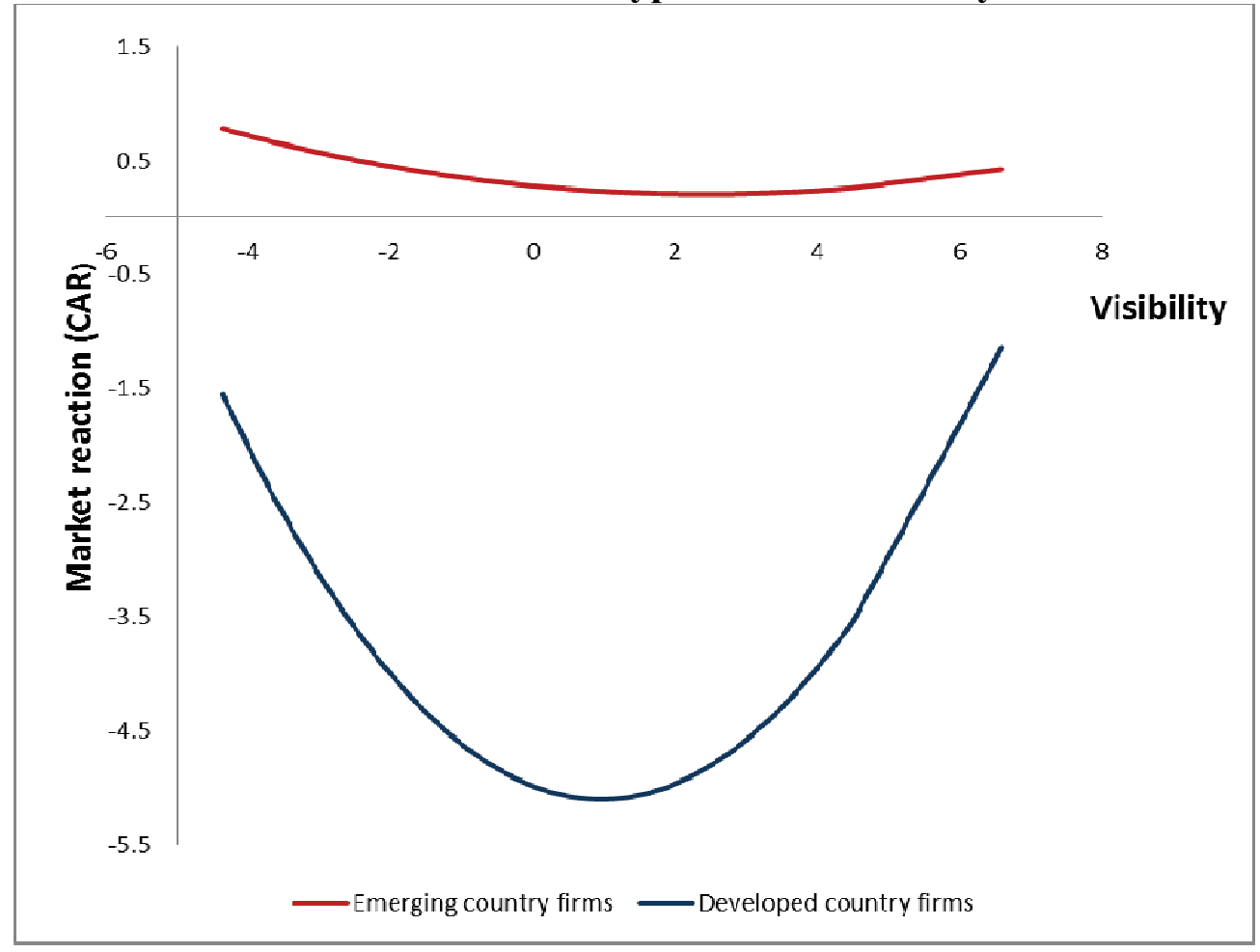


Table 3-1 Descriptive statistics and correlations

\begin{tabular}{|c|c|c|c|c|c|c|c|c|c|c|c|}
\hline & Mean & S.D. & 1 & 2 & 3 & 4 & 5 & 6 & 7 & 8 & 9 \\
\hline 1. $\operatorname{CAR}(-2,1)$ & .1535 & 1.606 & 1.000 & & & & & & & & \\
\hline 2. Age & 15.932 & 16.867 & -0.077 & 1.000 & & & & & & & \\
\hline 3. Financial Perf. & 6.986 & 7.908 & -0.075 & 0.033 & 1.000 & & & & & & \\
\hline 4. GDP growth & 2.808 & 4.426 & 0.007 & -0.111 & $0.196^{*}$ & 1.000 & & & & & \\
\hline 6. Visibility & .03331 & 1.9126 & $-0.185^{*}$ & 0.025 & 0.105 & $0.256^{*}$ & -0.050 & 1.000 & & & \\
\hline 7. Sq. Visibility & 3.6280 & 5.8606 & 0.172 & -0.157 & -0.030 & 0.142 & 0.152 & $0.314^{*}$ & 1.000 & & \\
\hline $\begin{array}{l}\text { 8. Sustainability Perf. } \\
\text { Disclosure }\end{array}$ & .5897 & .4940 & -0.116 & 0.140 & 0.054 & $-0.183^{*}$ & 0.077 & -0.114 & 0.119 & 1.000 & \\
\hline 9. Home country type & 0.231 & 0.423 & -0.048 & -0.171 & $0.195 *$ & $0.541 *$ & -0.020 & $0.384 *$ & $0.178^{*}$ & $-0.244^{*}$ & 1.000 \\
\hline
\end{tabular}

$\mathbf{N}=117 * \mathbf{p}<\mathbf{0 . 0 5}$ 
Table 3-2 Regression results for Market Reaction to UNGC participation Announcement (CAR: -2, +1)

\begin{tabular}{|c|c|c|c|c|c|c|}
\hline Variables & Baseline & $\begin{array}{l}\text { Model } 1 \\
\text { (H1 firm } \\
\text { visibility) }\end{array}$ & $\begin{array}{l}\text { Model } 2 \\
\text { (H2 ESG } \\
\text { disclosure) }\end{array}$ & $\begin{array}{l}\text { Model } 3 \\
\text { (H3a interaction } \\
\text { with visibility) }\end{array}$ & $\begin{array}{l}\text { Model } 4 \\
\text { (H3b interaction } \\
\text { with ESG info } \\
\text { disclosure) }\end{array}$ & $\begin{array}{l}\text { Model } 5 \\
\text { full model }\end{array}$ \\
\hline Financial performance & $\begin{array}{l}-.0141 \\
(.0194)\end{array}$ & $\begin{array}{l}-.0076 \\
(.0187)\end{array}$ & $\begin{array}{l}-.0035 \\
(.0185)\end{array}$ & $\begin{array}{l}-.0008 \\
(.0193)\end{array}$ & $\begin{array}{l}-.0048 \\
(.0187)\end{array}$ & $\begin{array}{l}-.0004 \\
(.0191)\end{array}$ \\
\hline Industry & $\begin{array}{l}-.0060 \\
(.0077) \\
\end{array}$ & $\begin{array}{l}-.0105 \\
(0076)\end{array}$ & $\begin{array}{l}-.0094 \\
(.0075)\end{array}$ & $\begin{array}{l}-.0102 \\
(.0076)\end{array}$ & $\begin{array}{l}-.0093 \\
(.0075)\end{array}$ & $\begin{array}{l}-.0104 \\
(.0076)\end{array}$ \\
\hline Home country economy growth & $\begin{array}{l}-.0372 \\
(.0348)\end{array}$ & $\begin{array}{l}-.0265 \\
(.0346)\end{array}$ & $\begin{array}{l}-.0396 \\
(.0346)\end{array}$ & $\begin{array}{l}-.0387 \\
(.0390)\end{array}$ & $\begin{array}{l}-.0576 \\
(.0401)\end{array}$ & $\begin{array}{l}-.0542 \\
(.0400)\end{array}$ \\
\hline Visibility & & $\begin{array}{l}-.2147 \\
(.0825)^{* *}\end{array}$ & $\begin{array}{l}-.2386 \\
(.0820)^{* *}\end{array}$ & $\begin{array}{l}-.2324 \\
(.0958) \dagger\end{array}$ & $\begin{array}{l}-.2575 \\
(.0856)^{* *}\end{array}$ & $(.0953)^{* *}$ \\
\hline Visibility Sq. & & $\begin{array}{l}.0761 \\
(.0267)^{* *}\end{array}$ & $\begin{array}{l}.0874 \\
(.0268) * * *\end{array}$ & $\begin{array}{l}.1217 \\
(.0379) * *\end{array}$ & $\begin{array}{l}.0841 \\
(.0270)^{* *}\end{array}$ & $\begin{array}{l}.1254 \\
(.0377)^{* * *}\end{array}$ \\
\hline Sustainability performance disclosure & & & $\begin{array}{l}-.6425 \\
(.3032)^{*} \\
\end{array}$ & $\begin{array}{l}-.6304 \\
(.3084)^{*}\end{array}$ & $\begin{array}{l}-.8583 \\
(.3539)^{* *}\end{array}$ & $\begin{array}{l}-.9006 \\
(.3531)^{* *}\end{array}$ \\
\hline ECF vs. DCF & & & & $\begin{array}{l}.2596 \\
(.4709) \\
\end{array}$ & $\begin{array}{l}-.1978 \\
(.4928)\end{array}$ & $\begin{array}{l}-.0618 \\
(.5124) \\
\end{array}$ \\
\hline Home country type* visibility & & & & $\begin{array}{l}.1931 \\
(.2720) \\
\end{array}$ & & $\begin{array}{l}.1793 \\
(.2704)\end{array}$ \\
\hline Home country type $*$ Sq.visibility & & & & $\begin{array}{l}-.1007 \\
(.0668) \dagger\end{array}$ & & -.1129 \\
\hline $\begin{array}{lccc}\text { Home country type } & * & \text { Sustainability } \\
\text { performance disclosure } & & \\
\end{array}$ & & & & & $\begin{array}{c}.9572 \\
(.7346) \\
\end{array}$ & $\begin{array}{l}1.1431 \\
(.7424) \dagger \\
\end{array}$ \\
\hline Number of observations & 117 & 117 & 117 & 117 & 117 & 117 \\
\hline R-squared & 0.03 & $0.12 * *$ & $0.15 * *$ & $0.17 * *$ & $0.17 * *$ & $0.19 * *$ \\
\hline Adjusted R-squared & -0.007 & 0.07 & 0.09 & 0.09 & 0.10 & 0.11 \\
\hline Constant & .684 & .437 & $.698 \dagger$ & .558 & $.844 * *$ & $.745 \dagger$ \\
\hline
\end{tabular}

$\dagger \mathbf{p}<0.1, * \mathbf{p}<0.05, * * \mathbf{p}<0.01, \quad * * * \mathbf{p}<0.001$. 


\section{REFERENCES}

Agarwal, R. \& Gort, M., (2002). Firm and Product Life Cycles and Firm Survival. The American Economic Review, 92 (2): 184.

Abernethy,R.B. (2006). The New Weibull Handbook Fifth Edition, Reliability and Statistical Analysis for Predicting Life, Safety, Supportability, Risk, Cost and Warranty Claims. Dr. Robert. Abernethy; 5th edition

Adams, M. \& Hardwick, P. (1998). An Analysis of Corporate Donations: United Kingdom Evidence. Journal of Management Studies, 35(5): 641-654.

Akerlof, G. A. (1970). Market for Lemons: Quality Uncertainty and Market Mechanism. Quarterly Journal of Economics, 84: 488-500.

Aldrich, H., \& Auster, E.E., (1986). Even Dwarfs Started Small: Liabilities of Age and Size and Their Strategic Implications. Research in Organizational Behavior, 8: 165-198.

Allison, P. D. 1984. Event history analysis: Regression for Longitudinal Event Data. Sage Publications, Beverly Hills, CA

Ameer, R., Ramli, F \& Zakaria, H.(2010). A new perspective on board composition and firm performance in an emerging market. Corporate Governance,10 (5): 647-661

Arora, A., Jaju, A., Kefalas, A. G., \& Perenich, T. (2004). An Exploratory Analysis of Global Managerial Mindsets: A Case of U.S. Textile and Apparel Industry. Journal of International Management, 10, 393-411.

Asian Development Bank. (2002). The Development of Private Enterprise in The People's Republic of China. Asian Development Bank: Manila.

Audretsch, David B., (1995). Innovation and Industry Evolution, Cambridge: MIT Press.

Banaszak-Holl, J., Ranger-Mooree, J., \& Hannan, M.T. (1990). Density Dependence in the Mortality Processes of Financial Institutionals: American Life Insurance Companies And Manhattan Banks. Technogical Report 90-1, Department of Sociology, Cornell University.

Bartlett, C. A. \& Ghoshal, S. (1989). Managing Across Borders: The Transnational Solution. Boston, MA: Harvard Business School Press.

Barney, J.B. (1991). Firm Resources and Sustainable Competitive Advantage. Journal of management, 17(1): 99-120. 
Barnett, W.P., (1990). The Organizational Ecology of a Technological System. Administrative Science Quarterly, 35: 31-60.

Bartlett, C., \& Ghoshal, S., (2000). Going Global: Lessons From Late Movers, Harvard Business Review, 78(2): 132-142.

Barnett, W.P., \& Amburgey, T.L., (1990). Do Larger Organizations Generate Stronger Competition? In Singh, J.V. (Ed). Organizational Evolution, New Directions: 78-102. Newbury Park, CA: Sage.

Baum, J. A. C., \& Oliver, C. (1992). Institutional Embeddedness and the Dynamics of Organizational Populations. American Sociological Review, 57: 540-559.

Bothner, M., (2005). Relative Size and Firm Growth in the Global Computer Industry. Industrial and Corporate Change, 14(4): 617

Bloomberg, (2010). ESG USA 2010 Global Trends and US Sustainable Investing, Bloomberg \& Social Investment Forum. New York, NY 10022.

Bowen, F.E. (1999). Does Organizational Slack Stimulate the Implementation of Environmental Initiatives?' In Wood, D. and Windsor, D. (Eds.) Proceedings of the Tenth Annual Meeting of the International Association of Business and Society: 234-244.

Bradsher, K., (2013/3/20). Chinese Solar Panel Giant Is Tainted by Bankruptcy. The New York Times. Retrieved from http://www.nytimes.com/2013/03/21/business/energyenvironment/chinese-solar-companys-operating-unit-declares-

bankruptcy.html?pagewanted $=$ all\&_r $=0$

Brammer, S, \& Millington, A. (2006). Firm Size, Organizational Visibility and Corporate Philanthropy: An Empirical Analysis, Business Ethics: A European Review, 15(1): 6-18.

Brown, S.J., Warner, J.B., (1985). Using Daily Stock Returns-The Case of Event Studies. Journal of Financial Economics, (14): 3-31.

Carpenter, M. A., \& Fredrickson, J. W. (2001). Top Management Teams, Global Strategic Posture, and the Moderating Role of Uncertainty. Academy of Management Journal, 44: 533-545.

Carpenter, M.A., Pollock, T.G. \& Leary, M.M. (2003). Governance, the experience of principals and agents, and global strategic intent: Testing a model of reasoned risk taking. Strategic Management Journal, 24: 803-820.

Carroll, G.R. \& Hannan, M.T., (1989). Density Dependence in the Evolution of Newspaper Populations. American Sociological Review, 54: 524-541 
Caves, R.E. (1998). Industrial Organization and New Findings on the Turnover and Mobility Of Firms. Journal of Economic Literature, 36(4): 1947-1982.

Certo, T. (2003). Influencing Initial Public Offering Investors with Prestige: Signaling With Board Structures. Academy of Management Review, 28(3): 432-446.

Certo, S. T., Covin, J. G., Daily, C. M., \& Dalton, D. R. (2001). Wealth and the Effects of Founder Management Among IPO-Stage New Ventures. Strategic Management Journal, 22: 641-658.

Cetindamar, D. \& Husoy, K. (2007). Corporate Social Responsibility Practices and Environmentally Responsible Behavior: The Case of the United Nations Global Compact. Journal of Business Ethics 76(2):163-176.

Chapman, D., Uggerslev, K. Carrol, S. Piasentin, K. \& Jones, D. (2005). Applicant Attraction to Organizations and Job Choice: A Meta-Analytic Review of the Correlates of Recruiting Outcomes. Journal of Applied Psychology, 90(5): 928-944.

Cuervo-cazurra,A.,\& Genc, M. (2008). Transforming Disadvantages into Advantages: Developing-Country MNEs in the Least Developed Countries. Journal of International Business Studies, 39(6): 957-979.

Damanpour, F. (1987). The Adoption of Technological, Administrative and Ancillary Innovations: Impact of Organizational Factors. Journal of Management, 13(4): 675-689.

Delios, A. \& Henisz, W.J., (2000). Japanese Firms' Investment Strategies in Emerging Economies, Academy of Management Journal, 43(3): 305-323.

DiMaggio, P. J. \& Powell, W. W. (1983). The Iron Cage Revisited: Institutional Isomorphism and Collective Rationality in Organizational Fields. American Sociological Review, 48(2): 147-160

Driffield, N. \& Munday, M. (1997). Industrial Performance, Agglomeration and Foreign Manufacturing Investment in the UK. Journal of International Business Studies, 31(1): 21-37.

Dunning, J.H. (1980). Toward An Eclectic Theory of International Production: Some Empirical Tests. Journal of International Business Studies, 11(1): 9-31.

Ehrhart, K. \& J. Ziegert. (2005). Why Are Individuals Attracted to Organizations? Journal of Management, 31: 901.

Erfle, S. \& McMillan, H. (1990). Media, Political Pressure, and the Firm: The Case of Petroleum Pricing in the Late 1970s. Quarterly Journal of Economics, 105(1):115-134. 
Fama, E. F. (1991). Efficient Capital Markets: II, The Journal of Finance, 46(5):15751617.

Feddersen, T. J. \& Gilligan, W., (2001). Saints and Markets: Activists and the Supply of Credence Goods. Journal of Economics and Management Strategy, 10(1):149-171.

Feito-Ruiz, I. \& Menendez-Requejo, S. (2011). Cross-border Mergers and Acquisitions in different legal environments. International Review of Law and Economics, 31(3): 169.

Fichman, M. \& Levinthal, D. A. (1991). Honeymoons and the Liability of Adolescence: A New Perspective on Duration Dependence in Social and Organizational Relationships. The Academy of Management Review, 16: (2): 442-468

Florin, J., Lubatkin, M., \& Schulze, W. (2003). A Social Capital Model of High-Growth by Building Legitimacy. Academy of Management Journal, 46: 374-384.

Folta, T. B., \& Janney, J. J. (2004). Strategic Benefits to Firms Issuing Private Equity Placements. Strategic Management Journal, 25: 223-242.

Freeman, J., Carrol,1 G. R. \& Hannan M. T., (1983). The Liability of Newness: Age Dependence in Organizational Death Rates. American Sociological Review, 48(5): 692710.

Hille, K. (2013/1/21). FT.com. Huawei in pledge to disclose more information. Retrieved from http://www.ft.com/cms/s/0/4b0ab5ce-6398-11e2-84d800144feab49a.html\#axzz2QNp0iKEs

Garnier G. (1982). Context and Decision Making Autonomy in the Foreign Affiliates of U.S. Multinational Corporations. Academy of Management Journal, 25(4): 893-908.

Gaur, A.S, Malhotra, S., \& Zhu, P., (2013). Acquisition Announcements and Stock Market Valuations of Acquiring Firms' Rivals: A Test of the Growth Probability Hypothesis in China. Strategic Management Journal, 34(2): 215-232

Greenaway, D. \& Milner, C. (1986). The Economics of Intra-Industry Trade. Boston: Basil Blackwell.

GRI News and Press Center, (2010). https://www.globalreporting.org/information/newsand-press-center/Pages/GRI-contributes-to-Harvard-E-book-on-integrated-reporting.aspx

Grubel, H. G. \& Lloyd, P. J. (1975). Intra Industry Trade. London: Macmillan.

Hair JF, Anderson RE, Tatham RL, Black WC. (1998). Multivariate Data Analysis with Readings. Prentice-Hall: Englewood Cliffs, NJ. 
Hambrick, D.C. \& Mason, P.A., (1984). Upper Echelons: The Organization as a Reflection of its Top Managers. Academy of Management Review, 9: 193 - 206.

Hannan, M.T. \& Freeman, J.H., (1977). The population Ecology of Organizations, American Journal of sociology, 82(5): 929-984.

Hannan, M.T. \& Freeman, J.H. (1984). Structural Inertia and Organizational Change. American Sociological Review, 49: 149-164

Hannan, M.T. \& Freeman, J.H. (1989). Organizational Ecology. Harvard University Press, Boston.

Hannan, M. T., Ranger-Moore, J., \& Banaszak-Hall, J. (1990). Competition and the Evolution of Organizational Size Distributions, Organizational Evolution, New Directions: 246-268. Newbury Park, CA: Sage.

Hassan, F. M.A. (1987). Intra-industry Trade: Theory and Evidence. Ph.D. dissertation, University of Pittsburgh.

Haveman, H., (1992). Between a Rock and a Hard Place: Organizational Change and Performance under Conditions of Fundamental Environmental Transformation. Administrative Science Quarterly, 37(1): 48-64.

Heil, O., \& Robertson, T. S. (1991). Toward a Theory of Competitive Market Signaling: a Research Agenda. Strategic Management Journal, 12: 403-418.

Hennart, J.F., \& Park, Y.R. (1993). Greenfield vs. Acquisition: the Strategy of Japanese Investors in the United States, Management Science, 39(9): 1054-1070.

Henderson, A. (1999). Firm Strategy and Age Dependence: A Contingent View of the Liabilities of Newness, Adolescence, and Obsolescence. Administrative Science Quarterly, 44: 281-314.

Holmes, R. M. (2008). Strategic Alliance Announcements and New Venture Stock Market Returns: Signaling and Resource-Based Perspectives on the Effects of Partner Firm, New Venture Firm, and Alliance Characteristics, Ph.D. dissertation. Texas A\&M University, UMI Dissertations Publishing

Howard E. A. \& Auster E., (1986). Even Dwarfs Started Small: Liabilities of Age and Size and Their Strategic Implications." Pp. 165-198 in Staw, B. \& Cummings L. L. (eds.), Research in Organizational Behavior, Vol. VIII. Greenwich, CT: JAI Press.

Hsu, C. \&; Liu, L. (2008). Corporate Diversification and Firm Performance: The Moderating Role of Contractual Manufacturing Model. Asia Pacific Management Review, 13(1): $345-360$ 
Huber, G. (1991). Organizational learning: The Contributing Processes and the Literature. Organization Science, 2: 88-115.

Hymer, S. H. (1976). The International Operations of National Firms: A Study of Direct Foreign Investment. PhD Diss. The MIT Press, Cambridge, Mass.

Janney, J. J. \& Folta, T. B., (2006). Moderating Effects of Investor Experience on the Signaling Value of Private Equity Placements. Journal of Business Venturing, 21(1): 2744.

Janney, J.J., Dess, G., \& Forlani, V., (2009). Glass Houses? Market Reactions to Firms Joining the UN Global Compact. Journal of Business Ethics, 90:407-423. DOI 10.1007/s10551-009-0052-X

Jensen, M. C. (1993). Modern Industrial Revolution, Exit, and the Failure of Internal Control Systems. Journal of Finance, 48: 831-880.

Jiang, C. X., \& Kim, J. (2005). Trading Costs of Non-U.S. Stocks On The New York Stock Exchange: The Effect of Institutional Ownership, Analyst Following, and Market Regulation. Journal of Financial Research, 28 (3): 439-459.

Johanson, J. \& Vahlne, J.E., (1977). The Internalization Process of the Firm: A Model of Knowledge Development and Increasing Foreign Market Commitments. Journal of international business studies, 8(1): 23-32.

Kalleberg, A. L. \& Leicht T. K. (1991). Gender and Organizational Performance: Determinants of Small Business Survival and Success. The Academy of Management Journal, 34(1): 136-161.

Kalafsky, R. V., (2004). Export Activity and Firm Size: An Examination of the Machine Tool Sector. Journal of Small Business and Enterprise Development, 11(2): 159-165.

Khanna, T., \& Palepu, K., (2006). Emerging Giants: Building World-Class Companies in Developing Countries, Harvard Business Review, 84(10): 60-69

Klepper, S. (2002). Firm Survival and the Evolution of Oligopoly', RAND Journal of Economics, 33(1): 37-61.

Kogut, B. (1988). Joint Ventures: Theoretical and Empirical Perspectives. Strategic Management Journal, 9: 319-332.

Koh, J., \& Venkatraman, N. (1991). Joint Venture Formations and Stock Market Reactions: An Assessment in the Information Technology Sector. Academy of Management Journal, 34: 869-892. 
Kostova, T., (1999). Transnational Transfer of Strategic Organizational Practices: A Contextual Perspective. Academy of Management Review, 24(2): 308-324

La Porta, R., Lopez-de-Silanes, F., \& Shleifer, A. (2008). The Economic Consequences of Legal Origins. Journal of Economic Literature, 46(2): 285-332.

Lee, P. M., (2001). What's In a Name.Com? : The Effects of '.Com' Name Changes on Stock Prices and Trading Activity. Strategic Management Journal, 22: 793-804.

Levinthal, D. A. \& March, J.G., (1993). The Myopia of Learning. Strategic management journal, 14(8): 95-112

Levy, O. (2005).The Influence of Top Management Team Attentional Patterns on Global Strategic Posture of Firms. Journal of Organizational Behavior, 26(7): 797-819.

Li, J., (1992). Survival of Foreign Subsidiaries: An Event History Study of Foreign Firms in the United States. ProQuest Dissertations and Theses.

Li, J., (1992). Survival of Foreign Subsidiaries: An Event History Study of Foreign Firms in the United States. ProQuest Dissertations and Theses, ProQuest

Luo, Y. \& Tung, R.L., (2007). International Expansion of Emerging Market Entreprises: A Springboard Perspective. Journal of International Business Studies 38: 481-498.

MacKinlay, A. C., (1997). Event Studies in Economics and Finance. Journal of Economic Literature, 35 (1): 13-39.

Madhavan, R., \& Prescott, J. E. (1995). Market Value Impact of Joint Ventures: The Effect of Industry Information Processing Load. Academy of Management Journal, 38: 900-915.

Madhok, A \& Keyhani, M., (2012). Acquisitions as Entrepreneurship: Asymmetries, Opportunities, and the Internationalization of Multinationals from Emerging Economies. Global Strategy Journal, 2: 26-40

Makhija, M.V., Kim, K., \& Williamson, S. D. (1997). Measuring Globalization of Industries Using a National Industry Approach: Empirical Evidence across Five Countries and over Time. Journal of International Business Studies, 28 (4): 679-710

Makino, S., Lau, C.M., \& Yeh, R.S., (2002). Asset-Exploitation versus Asset-Seeking: Implications for Location Choice of Foreign Direct Investment from Newly Industrialized Economies, Journal of International Business Studies, 33(3): 403-421. 
Marcus, A. \& Goodman, R. (1991). Victims and Shareholders: The Dilemmas of Presenting Corporate Policy During A Crisis. Academy of Management Journal, 34(2): 281-305.

McEnrue, M. P. (1988). Length of Experience and the Performance of Managers in the Establishment Phase of Their Careers. Academy of Management Journal, 31(1): 175-184.

McWilliams, A. \& Siegel, D. (1997). Event Studies in Management Research: Theoretical and Empirical Issues. Academy of Management Journal, 40(3): 626-657

Meyer, J. W. \& Rowan, B. (1977), 'Institutional Organizations: Formal Structure as Myth and Ceremony', American Journal of Sociology, 83(2):340-363.

Meznar, M.B. \& Nigh, D. (1995). Buffer or bridge? Environmental and Organizational Determinants of Public Affairs Activities in American Firms. Academy of Management Journal, 38 (4):975-996.

Miles, R. (1987). Managing the Corporate Social Environment: A Grounded Theory. Englewood Cliffs, NJ: Prentice-Hall.

Milgrom, P. \& Roberts, J. (1986). Price and Advertising Signals of Product Quality. Journal of Political Economy, 94 (4): 796

Miller, S. R., Thomas,D. E, Eden, L., \& Hitt, M. (2008). Knee Deep in the Big Muddy: The Survival of Emerging Market Firms in Developed Market. Management International Review, 48(6): 645-665.

Miller, S.R. \& Eden, L.,(2006). Local Density and Foreign Subsidiary Performance. Academy of Management Journal, 49(2): 341-355.

Mitchell, W. (1989). Whether and When: Probability and Timing of Incumbents' Entry into Emerging Industrial Subfields. Administrative Science Quarterly, 34: 208-230.

Mitchell, W. (1994). The Dynamics of Evolving Markets: The Effects of Business Sales and Age on Dissolutions and Divestitures. Administrative Science Quarterly, 39(4): 575602.

Mitchell,W. Shaver, J.M. \& Yeung, B., (1994). Foreign Entrant Survival and Foreign Market Share: Canadian Companies' Experience in United States Medical Sector Markets. Strategic Management Journal, 15(7): 555-567.

Morita, J G; Lee, T W; Mowday, R T. (1989). Introducing Survival Analysis to Organizational Researchers: A Selected Application to Turnover Research. Journal of Applied Psychology, 74(89): 280-292. 
Mudambi, R. \& Zahra, S.A., (2007). The survival of International New Ventures. Journal of International Business Studies, 38: 333-352.

Mudambi, R. (1998). The Role of Duration in Multinational Investment Strategies. Journal of International Business Studies, 29(2): 239-262.

Nessereddine,M., (2012). Three Empirical Essays on Startups' Survival Using the Kauffman Firm Survey. Ph.D Diss. Florida International University.

Oliver, C. (1991). Strategic Responses to Institutional Processes. Academy of Management Review, 16 (1): 145-179.

O’Neil, M., (2004). Curbs Choke Private Enterprise. SCMP, South China Morning Post, August 31, B2.

Oxelheim, L. \& Randøy,T., (2005). The Anglo-American financial influence on CEO compensation in non-Anglo-American firms. Journal of International Business Studies, 36: $470-483$.

Patten, D. M. (1992). Intra-Industry Environmental Disclosures in Response to the Alaskan Oil Spill: A Note on Legitimacy Theory. Accounting, Organizations and Society, 17(5): 471-475.

Paul,K., Meyskens, M., \& Robbins, (2011). Components of A Global Mindset: Corporate Social Responsibility And Cross-Cultural Sensitivity. Journal of International Business and Cultural Studies, 1-3A.

Penrose, E.T., (1959), The Theory of the Growth of the Firm, New York: Wiley.

Perlmutter, H. (1969). The Tortuous Evolution of the Multinational Corporation. Columbia World Journal of Business, 9-18.

Pfeffer, J. \& Salancik, G. R., (1978). The External Control of Organizations: A Resource Dependence Perspective. Harper \& Row, New York.

Porter, M.E. (1980). Competitive Strategy, The Free Press: New York, NY.

Porter, Michael E. (1986). Competition in Global Industries: A Conceptual Framework. In M. Porter, editor, Competition in global industries. Boston: Harvard Business School Press. 1990.

Ramamurti, R., \& Singh, J. (2008). Emerging Multinationals from Emerging Markets. Cambridge: Cambridge University Press. 
Ranger-Moore J., (1997). Bigger May Be Better, But Is Older Wiser? Organizational Age and Size in the New York Life Insurance Industry. American Sociological Review, 62 (6):903-920.

Rao, H., (1994). The Social Construction of Reputation: Certification Contests, Legitimation, and the Survival of Organizations in the American Automobile Industry 1895-1912, Strategic Management Journal, 15(1): 29-44.

Rhinesmith, S.H. (1992). Global Mindsets for Global Managers, Training \& Development, 46(10): 63-69.

Ross, S.A. (1977). The Determinants of Financial Structure: The Incentive Signaling Approach. Bell Journal of Economics, 8:23-40

Rossi, S. \& Volpin, P. F., (2004). Cross-Country Determinants of Mergers and Acquisitions. Journal of Financial Economics, 74 (2): 277-304.

Rugman, A. (2008). Chapter "Theoretical Aspect of MNEs from Emerging Economies" in the book Emerging multinationals in emerging markets by Ramamurti, R \& Singh, J.V.Cambridge.

Rugman A. M. \& Verbeke, A. (2003). Extending the Theory of The Multinational Enterprise: Internalization and Strategic Management Perspectives. Journal of International Business Studies, 34: 125-137. doi:10.1057/palgrave.jibs.8400012

Saiia, D.H. (2000). Measuring "Business Exposure": An Empirical Measure of Stakeholder Influence and Enterprise Visibility. Presented at the IABS meeting.

Sambharya, R. (1996). Foreign Experience of Top Management Teams and International Diversification Strategies of US Multinational Corporations. Strategic Management Journal, 17(9):739-746.

Saridakis ,G. Mole, K., \& Storey, D. J., (2008). New Small Firm Survival in England Empirica 35:25-39 DOI 10.1007/s10663-007-9049-9

Shepherd, D. and Douglas, E. (2000). New Venture Survival: Ignorance, External Shocks and Risk Reduction Strategies. Journal of Business Venturing, 15(5-6): 394-312.

Shi, Y., Magnan, M., \& Kim, J. B. (2012). Do countries matter for voluntary disclosure? Evidence from Crosslisted Firms in the US. Journal of International Business Studies, 43:143-165.

Shrader, R., Oviatt, B. and McDougall, P.P. (2000). How New Ventures Exploit TradeOffs Among International Risk Factors: Lessons for the Accelerated Internationalization of The 21st Century. Academy of Management Journal, 43(6): 1227-124. 
Smith, P.B., Peterson, M.F., \& Wang, Z.M. (1996). The Manager as Mediator of Alternative Meanings: A Pilot Study from China, The USA And UK. Journal of International Business Studies, 27(1): 115-137.

Simon, H., (1991). Bounded Rationality and Organizational Learning. Organization Science, 2(1): 125-134.

Singh, J.V., Tucker, D.J., \& House, R., (1986). Organizational Legitimacy and the Liability of Newness. Administrative Science Quarterly, 31(2): 171-194.

Spence, M. (1973). Job market signaling. Quarterly Journal of Economics, 87: 355-374.

Spence, M. (1974). Market Signaling: Information Transfer in Hiring and Related Processes. Cambridge, MA: Harvard University Press.

Spence, M. (2002). Signaling in Retrospect and the Informational Structure Of Markets. American Economic Review, 92: 434-459.

Standard \& Poor's (S\&P). (2002). Transparency and Disclosure: Overview of Methodology and Study Results-United States. New York, NY: S\&P.

Stinchcombe, A. L.(1965). Social Structures and Organizations, in J. M. March (ed.), Handbook of Organizations (Rand McNally, Chicago), 142-193.

Stuart, T. E., Hoang, H. \& Hybels, R. C. (1999). Interorganizational Endorsements and the Performance of Entrepreneurial Ventures', Administrative Science Quarterly, 44(2): 315-349. doi:10.2307/2666998.

Tan, A. T. L, (2010). International Experience and Growth and Survival-Enhancing Learning of DE NOVO Firms: A Study of U.S. DOT-COM Startups, 1994-2007. ProQuest Dissertations and Theses.

Tabachnick BG, Fidell LS. (2007). Using Multivariate Statistics. Pearson: Boston, MA.

De La Merced, M. J. \& Barboza, D.(2013/05/29). The New York Times. Needing Pork, China Is to Buy a U.S. Supplier. Retrieved from http://dealbook.nytimes.com/2013/05/29/smithfield-to-be-sold-to-shuanghui-group-of-china/

China Scope Financial. (2011/12/16). Little Sheep: to Delist Next February. China Scope Financial. Retrieved from http://www.chinascopefinancial.com/en/news/post/2119.html

Thomas, D.E., Eden, L., Hitt, M \& Miller, S.R. (2007). Experience of Emerging Market Firms: The Role of Cognitive Bias in Developed Market Entry and Survival. Management International Review, 47(6): 845-867. 
Titman, S., \& Trueman, B. (1986). Information Quality and the Valuation of New Issues. Journal of Accounting \& Economics, 8: 159-172.

USA Today. (2011). 2011/12/28 Some Chinese Companies Giving Up Their U.S. Stock Listings. $\quad \mathrm{http}: / / \mathrm{www}$. usatoday.com/money/markets/story/2011-12-28/china-reversemergers $/ 52258810 / 1$

Vermeulen, F., \& Barkema, H. (2001). Learning Through Acquisitions. Academy of Management Journal, 44: 457-476.

Waddock, S. (2004). Creating Corporate Accountability: Foundational Principles to make Corporate Citizenship Real. Journal of Business Ethics 50(4):313-327. DOI:10.1023/B:BUSI.0000025080.77652.a3.

Wilson, A. (2002). Predicting Survival of High-Technology Initial Public Offering Firms. Journal of High Technology Management Research (13): 127-141

Winter, S. (2000). The Satisficing Principle in Capability Learning. Strategic Management Journal, 21: 981-996.

Wolf, J. (2012/10/8). China's Huawei, ZTE Should Be Banned: US Lawmakers. NBC News Business. Retrieved from http://www.nbcnews.com/business/chinas-huawei-zteshould-be-banned-us-lawmakers-1C6335293

World Governance Indicators, World Bank (2011). www.govindicators.org

Wu, J. (2002). Six issues on China corporate governance. China.com. http://www.china.com.cn/chinese/zhuanti/169140.htm

Zaheer, S. (1995). Overcoming the Liability of Foreignness. Academy of Management Journal, 38 (2):341-363.

Zahra S. A. \& George, G. (2002). Absorptive Capacity: A Review, Reconceptualization, and Extension. The Academy of Management Review, 27(2): 185-203

Zimmerman, M. \& Zeitz, G., (2002). Beyond Survival: Achieving New Venture Growth by Building Legitimacy. Academy of Management Review, 27(3): 414-431.

Zollo, M. \& Meier, D., (2008). What is M\&A performance?. Academy of Management Perspective, 22: 55-77. 
VITA

\section{KUN YANG}

Born, Tianjin, China

$\begin{array}{ll}\text { 1998-2002 } & \begin{array}{l}\text { B.A., Management } \\ \text { Xiamen University } \\ \text { Xiamen, China }\end{array} \\ & \\ 2002-2005 & \begin{array}{l}\text { M.A., Management } \\ \text { Xiamen University } \\ \text { Xiamen, China }\end{array} \\ & \\ 2005-2008 & \begin{array}{l}\text { Instructor, Assistant Professor, } \\ \text { Tianjin University of Commerce } \\ \text { Tianjin, China }\end{array} \\ & \\ & \begin{array}{l}\text { Doctoral Candidate } \\ \text { Florida International University } \\ \text { Florida, U.S. }\end{array}\end{array}$

\section{PUBLICATIONS AND MAIN PRESENTATIONS}

Yang, K. (2007). Harmonizing the conflicts of travel agent firms' stakeholders. Contemporary Eco-Agriculture, 36(2): 43-45

Yang, K. (2004). Issues on transferring the operation right of state-owned scenic spots from government to firms. Fujian Tourism Forum, 5: 68-81

Yang, K., Zhao, J.(2013). Blazing a new trail? The path of internationalization of Chinese firms, 18th Annual Graduate Student Research Conference in Hospitality and Tourism, Seattle, WA

Yang, K. (2012). The Comparison on the Survival of Emerging Country Firms and Developed Country Firms Operating In the U.S. European International Business Academy 2012, 26th EIBA / EIASM John H. Dunning Doctoral Tutorial in International Business, Brighton, U.K. 
Wang, Y., Yang, K., \& Hiller, N. (2012). The Impact of International Diversification on CEO Turnover. competitive session at Academy of International Business (AIB), Washington, D.C.

Yang,K., \& He,W. (2011). Contract or acquisition? -The determinants of entry choices of international hotels. paper (competitive) session at Strategic Management Society (SMS) 2011 Annual conference, Miami U.S.

Kelly, Yang, \& Newburry. (2011). Service Characteristics, Deregulation, and Firm reputation: Comparing Telecom and Banking Industries in Latin America. Presentation at the SMS Special Conference 2011, Rio de Janeiro, Brazil

Yang, K. \& Zhao, J. (2011). Agenda of international entry choice research in the hospitality management field. The 16th Annual Graduate Education and Graduate Student Research Conference in Hospitality and Tourism, 2011, Houston, U.S.

Kelly, K. Thams,Y. Alvarado-Vargas, M. \& Yang, K. (2010). Institutional Distance During Uncertainty: When Foreignness isn't such a Liability. SMS Conference, Rome, Italy.

Yang, K. \& He, W. (2010). The trade-off effect of formal and informal institutional distance on the cross-border M\&A activities. Academy of Management, Montréal, Canada.

Yang, K \& Buschman, J (2010). A Dyadic Perspective on Determinants of Entry Choices in the Global Hospitality Industry. AIB 2010, Rio de Janeiro, Brazil. 